\title{
CONDENSATION CORROSION: A THEORETICAL APPROACH
}

\section{KONDENZACIJSKA KOROZIJA: TEORETIČNI PRISTOP}

\author{
WOLFGANG DREYBRODT ${ }^{1,2}$, FRANCI GABROVŠEK ${ }^{2}$ \\ $\&$ MATIJA PERNE 3
}

\footnotetext{
${ }^{1}$ Karst Processes Research Group, University of Bremen, Germany

${ }^{2}$ Karst Research Institute, ZRC SAZU, Titov trg 2, SI-6230 Postojna, Slovenia

${ }^{3}$ Student, Faculty of Mathematics and Physics, University of Ljubljana, Slovenia

Prejeto / Received: 20. 9. 2005
}

Prejeto / Received: 20. 9. 2005 


\section{Wolfgang Dreybrodt, Franci Gabrovšek \& Matija Perne: Condensation corrosion: A theoretical ap- proach}

Condensation of water from warm, humid air to cold rock walls in caves is regarded to play a significant role in speleogenesis. The water condensing to the cave walls quickly attains equilibrium with the carbon dioxide in the surrounding air, and consequently dissolves limestone or gypsum forming various types of macro- ,meso-, and micromorphologies. In this paper we present the basic physical principles of condensation and give equations, which allow a satisfactory estimation of condensation rates. Water condensing to a cooler wall releases heat of condensation, which raises the temperature of the wall thus reducing the temperature difference $\Delta \mathrm{T}$ between the warm air and the cave wall. Furthermore one has to take into account the heat flux from the air to the cave wall. This defines the boundary conditions for the equation of heat conduction. For a constant temperature of the air initial condensation rates are high but then drop down rapidly by orders of magnitude during the first few days. Finally constant condensation rates are attained, when the heat flux into the rock is fully transmitted to the surface of the karst plateau. For spherical and cylindrical conduits these can be obtained as a function of the depth $\mathrm{Z}$ below the surface. When diurnal or seasonal variations of the air temperature are active as is the case close to cave entrances, condensation rates can become quite significant, up to about $10^{-6} \mathrm{~m} / \mathrm{year}$. The theoretical results are applied also to corrosion of speleothems and the formation of »röhrenkarren « as described by Simms (2003). To convert condensation rates into retreat of bedrock the saturation state of the solution must be known. In the appendix we present experiments, which prove that in any case the solution flowing off the rock is saturated with respect to limestone or gypsum, respectively.

Key words: condensation, corrosion, speleogenesis, heat transfer.

\section{Izvleček}

UDK: 551.435.8:551.3.053

\section{Wolfgang Dreybrodt, Franci Gabrovšek \& Matija Perne: Kondenzacijska korozija: teoretični pristop}

O speleogenetskem pomenu vode, ki iz toplega vlažnega zraka kondenzira na hladne jamske stene je napisanega veliko. Kondenzirana voda se hitro uravnoteži z ogljikovem dioksidom v jamski atmosferi, zato raztaplja apnenec in pri tem tvori različne skalne oblike. $V$ članku predstavimo fizikalne osnove in podamo enačbe, ki omogočajo približno oceno hitrosti kondenzacije v različnih pogojih. Zaradi kondenzacijske toplote in prenosa toplote iz zraka na steno, se temperatura stene viša, pri čemer se zmanjšuje razlika temperature med zrakom in steno. To predstavlja robni pogoj za prevajanje toplote iz jame. Pri konstantni temperaturi zraka, hitrost kondenzacije v nekaj dneh pade za več velikostnih redov, dokler ne doseže končne vrednosti, pri kateri se ves toplotni tok prenese na površje. Slednjo za primer krogelnih in valjastih prostorov opišemo kot funkcijo globine rova Z. Pri dnevnih in sezonskih spemembah temperature, značilnih v bližini jamskih vhodov, je hitrost kondenzacije in posledično korozije do $1 \mu \mathrm{m}$ na leto. Teoretične rezultate uporabimo tudi za izračun korozije kapnikov in tipa škrapelj (röhrenkarren), ki jih opisuje Simms (2003). Za pretvorbo hitrosti kondenzacije v hitrost korozije, potrebujemo podatek o stopnji nasičenja vode. $\mathrm{V}$ dodatku predstavimo poskus, ki dokazuje, da se voda, ki kondenzira na jamske stene, hitro nasiti tako v primeru apnenca kot v primeru sadre.

Ključne besede: kondenzacija, korozija, speleogeneza, prevajanje toplote. 


\section{INTRODUCTION}

Water vapor from a cave atmosphere condensing to the walls of a cave creates a water film in equilibrium with the partial pressure $\mathrm{p}_{\mathrm{CO} 2}$ of the cave atmosphere. This solution is therefore aggressive to limestone and the dissolution process based on it has been termed condensation corrosion.

The most recent and comprehensive review on condensation in karst and its role on hydrology and speleogenesis has been published by Dublyansky and Dublyansky (2000) and Klimchouk et al. (1996). They report that in summer condensation supplies a significant amount of water (up to $20 \%$ of the total dry reason run-off) to karst systems.

They also discuss the role, condensation corrosion plays in sculpturing cupolas in limestone and in gypsum caves, when evaporation from open water surfaces at elevated temperature, above that of the cave wall, produces warm cave air saturated with water vapor. Condensation of water to the cave walls supplies an aggressive solution, which runs down the cave wall and is replaced by fresh, condensing water. Cigna and Forti (1986) and Calafora at al. (1993) have reported on field measurements of condensation. Large cupolas in limestone and gypsum caves are explained by this mechanism which schematically is shown in Fig. 1 (Audra et al. 2002) .

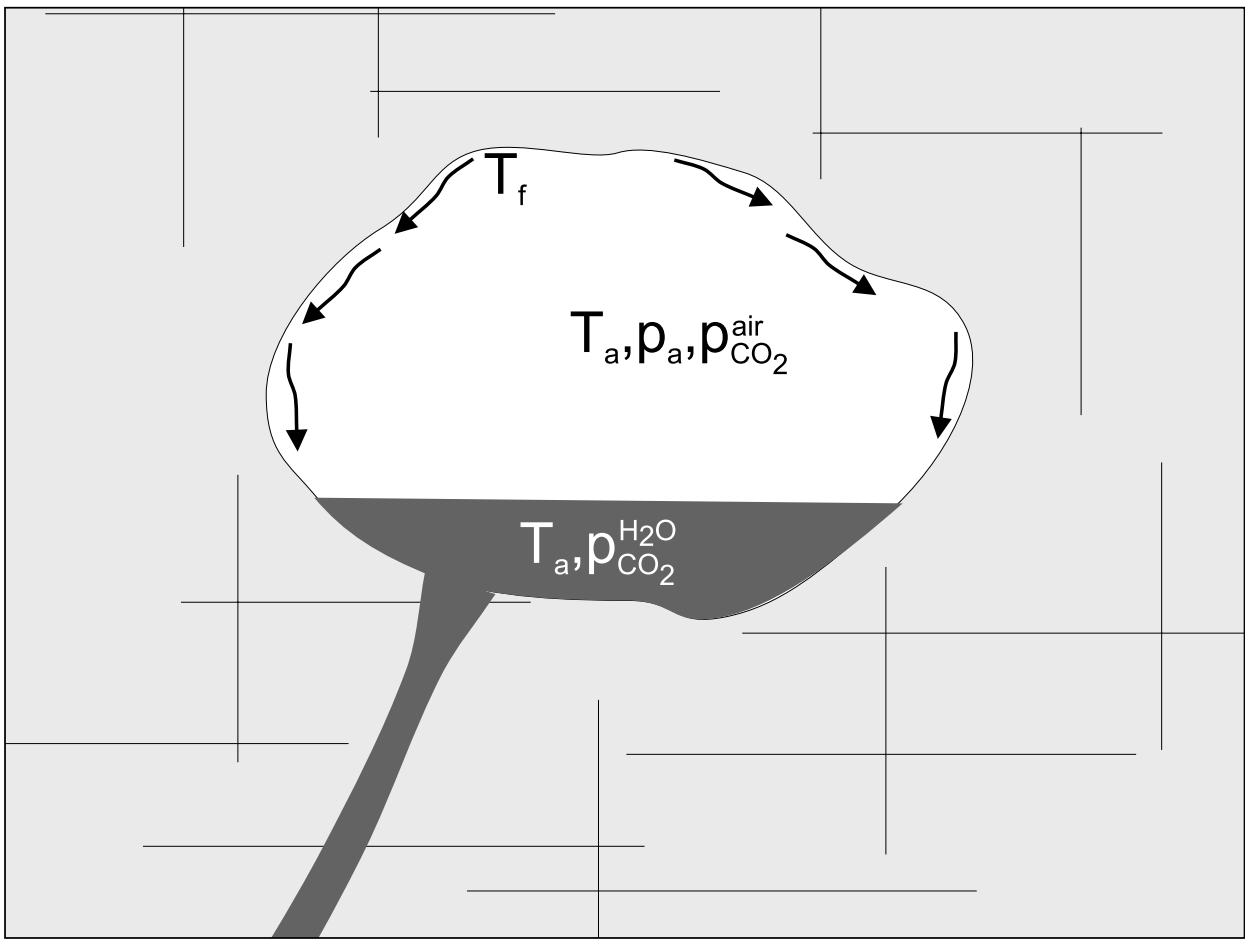

Fig. 1: Water evaporates from an open surface of elevated temperature Ta to the cave air in thermal equilibrium with the water. Vapor pressure at temperature $T_{a}$ is given by $p_{a}$. The partial pressure $p_{\mathrm{CO}_{2}}^{\text {air }}$ in the air is in equilibrium with $p_{\mathrm{CO}_{2}}$ in the water. The vapor condenses at the cave wall with temperature $T_{f}<T_{a}$ and flows back as a thin film, designated by arrows. These water films become saturated with respect to the mineral composing the rock (limestone or gypsum). 
The free surface of water at elevated temperature $\mathrm{T}_{\mathrm{a}}$ could be a lake of hydrothermal water. Water condenses at the cave walls if their temperature $\mathrm{T}_{\mathrm{f}}$ is below the dew point of the air. The condensed water flows back in a thin film covering the cave walls. As long as the temperatures $\mathrm{T}_{\mathrm{a}}$ and $\mathrm{T}_{\mathrm{f}}$ are constant in time this is a continuous, everlasting process.

To estimate the dissolution rate one has to know the wall temperature $\mathrm{T}_{\mathrm{f}^{\prime}}$ If initially the cave wall and the surrounding rock is at temperature $T_{f}$, water from the air with temperature $T_{a} \geq T_{f i}$ starts to condense to the wall. This causes a continuous flow of heat into the rock. A small part of it is due to heat transfer from the warmer air into the cold rock. The major part stems from release of heat of condensation from the condensing water. This heat transfer increases the temperature of the cave wall, causing reduction of the rate of condensing water. Eventually a stationary state is reached and the temperature of the cave wall, $\mathrm{T}_{\mathrm{f}}^{\text {stat }}$ becomes independent of time.

It is also possible that the temperature of the open surface changes diurnally or seasonally, e.g. a river flowing into the cave at elevated temperature during day time (summer) and at low temperature during night (winter).

In this paper, we address the question, what are the rates of condensation and what average annual retreat of bedrock follows as consequence.

The first part of this paper presents a theory of condensation rates for the stationary state of condensation for time independent temperature of the cave air, fully saturated with water vapor. Then we will turn to situations where the air temperature in the cave changes diurnally or seasonally. These results will be also applied to corrosion of speleothems, which is an important topic in conservation of tourist caves (Avramidis et al. 2001). A recently observed form of small scale cupolas of a few $\mathrm{cm}$ diameter and a length of about $10 \mathrm{~cm}$, growing upwards from bedding planes of limestone at a lake shore (Simms 2003) is also explained by our theoretical findings.

To translate rates of condensation into bedrock retreat in $\mathrm{m} / \mathrm{year}$ one has to know the saturation state of the water, when it flows off the rock. In the appendix we present laboratory experiments on limestone and gypsum, which prove that those waters are saturated with respect to limestone and gypsum, respectively, in all relevant situations.

This work shall provide a theoretical basis to the interpretation of field data. Therefore we assume two scenarios of boundary conditions: a) stable, time independent temperature of the cave air or b) periodic variations in temperature, diurnally or seasonally. We do not ask the question, how these conditions arise in detail. This question deals with cave climate and is a complex subject (Badino 1995; Wigley \& Brown 1976). Our question to be answered is: How effective under given boundary conditions is water condensation to the cave walls or to speleothems, and what are the rates of condensation corrosion?

\section{BASIC THEORY}

The amount of water condensing to an exposed rock surface per unit of time and surface area determines the retreat of rock by dissolution. Therefore, it is of utmost importance to give a reliable estimation. We assume that the exposed surface of the rock is covered by a thin film of condensed water, about $10^{-2} \mathrm{~cm}$ deep. Such a thin film will quickly come to thermal equilibrium with the temperature $\mathrm{T}_{\mathrm{f}}$ of the cave wall. It keeps its constant depth since there is flow from the rock surface down to the cave floor, which compensates for condensing water. 
Water condenses to the film, if the partial pressure $\mathrm{P}_{\mathrm{a}}$ of vapor in the cave air exceeds the vapor pressure $\mathrm{P}_{\mathrm{f}}$ at the temperature $\mathrm{T}_{\mathrm{f}}$ of the water film. In the following, we assume that the cave air is saturated, i.e. relative humidity is $100 \%$.

For condensation, water molecules must be transported to the cave wall, where they attach to the water film. We assume that the cave air is well mixed, but close to the rock a diffusion boundary of thickness $\varepsilon_{D}[\mathrm{~m}]$ exists. Transport of water molecules is effected through this layer by molecular diffusion. The flux of vapor $F_{v}$ to the surface of the film is given by Fick's law as

$$
F_{V}=\frac{D_{m}}{\varepsilon_{D}}\left(c_{a}-c_{f}\right) \quad\left[\mathrm{gm}^{-2} \mathrm{~s}^{-1}\right]
$$

where $\mathrm{D}_{\mathrm{m}}$ is the constant of molecular diffusion of water molecules in air $\left(\mathrm{D}_{\mathrm{m}}=2.5 \cdot 10^{-5} \mathrm{~m}^{2} / \mathrm{s}\right), \mathrm{c}_{\mathrm{a}}$ and $\mathrm{c}_{\mathrm{f}}$ are the concentrations in $\mathrm{g} / \mathrm{m}^{3}$ of water vapor at temperatures $\mathrm{T}_{\mathrm{a}}$ and $\mathrm{T}_{\mathrm{f}}$ respectively. By use of the equation for ideal gases this can be written as

$$
F_{v}=\frac{D_{m}}{\varepsilon_{D}} \cdot \frac{\left(P_{a}-P_{f}\right)}{R T_{a}} \cdot M \quad\left[\mathrm{gm}^{-2} \mathrm{~s}^{-1}\right]
$$

$\mathrm{P}_{\mathrm{a}}$ and $\mathrm{P}_{\mathrm{f}}$ are the vapor pressures measured in $\mathrm{Pa}, \mathrm{T}_{\mathrm{a}}$ is the temperature of the cave air in $\mathrm{K}$. In all following calculations we use $\mathrm{T}_{\mathrm{a}}=300 \mathrm{~K} . \mathrm{M}=18 \mathrm{~g} / \mathrm{mol}$ is the molecular weight of water and $\mathrm{R}$ is the universal gas constant $\mathrm{R}=8.314 \mathrm{~J} \mathrm{~mol}^{-1} \mathrm{~K}^{-1}$. $\mathrm{P}_{\mathrm{a}}-\mathrm{P}_{\mathrm{f}}$ can be approximated by

$$
P_{a}-P_{f}=\frac{\Delta P}{\Delta T}\left(T_{a}-T_{f}\right)
$$

where $\Delta \mathrm{P} / \Delta \mathrm{T}=100 \mathrm{~Pa} / \mathrm{K}$ for the temperatures of interest.

The vapor condensing to the water film releases heat of condensation $q_{c}=2450 \mathrm{~J} / \mathrm{g}$. This is a very high amount of energy. A condensation rate of $1 \mathrm{~mm} / \mathrm{day}=1 \mathrm{~kg} /\left(\mathrm{m}^{2}\right.$ day $)$ causes a heat flux of $28 \mathrm{~W} / \mathrm{m}^{2}$, equivalent to the heat produced by lightening the cave by electrical bulbs of $28 \mathrm{~W}$, with one bulb on each square meter of the cave walls.

The flux of heat $\mathrm{F}_{\mathrm{q}}$ released by condensation is given by

$$
F_{q}=q_{c} \cdot F_{v}=q_{c} \cdot \frac{D_{m}}{\varepsilon_{D}} \cdot \frac{M}{R T_{a}} \cdot \frac{\Delta P}{\Delta T} \cdot\left(T_{a}-T_{f}\right)=\frac{4.42 \cdot 10^{-2}}{\varepsilon_{D}}\left(\mathrm{~T}_{\mathrm{a}}-\mathrm{T}_{\mathrm{f}}\right) \quad\left[\mathrm{Wm}^{-2}\right] \quad 4
$$

An additional flux from the warm cave air to the cooler water film is given by

$$
F_{c}=\frac{k_{a}}{\varepsilon_{T}}\left(T_{a}-T_{f}\right)=\frac{2.6 \cdot 10^{-2}}{\varepsilon_{T}}\left(\mathrm{~T}_{\mathrm{a}}-\mathrm{T}_{\mathrm{f}}\right) \quad\left[\mathrm{Wm}^{-2}\right]
$$

$\mathrm{k}_{\mathrm{a}}$ is the thermal conductivity of air $\left(2.6 \cdot 10^{-2} \mathrm{Wm}^{-1} \mathrm{~K}^{-1}\right)$ and $\varepsilon_{\mathrm{T}}$ is the thickness of the thermal boundary layer, which is related to $\varepsilon_{\mathrm{D}}$ by $\varepsilon_{\mathrm{D}}=\varepsilon_{\mathrm{T}}(\mathrm{Sc} / \mathrm{Pr})^{1 / 3}$. Sc is the $\mathrm{Schmidt}$ number for diffusion and $\operatorname{Pr}$ the Prandtl number for heat convection(Beek \& Muttzall 1975). For air, $\operatorname{Sc}=\operatorname{Pr}=1$. Therefore $\varepsilon_{\mathrm{D}}=\varepsilon_{\mathrm{T}}=\varepsilon$.

The total heat flux to the water film is the sum of Eqs. 4 and 5

$$
F_{\text {tot }}=\frac{k}{\varepsilon}\left(T_{a}-T_{f}\right), \quad \mathrm{k}=0.0702 \mathrm{Wm}^{-1} \mathrm{~K}^{-1}
$$

This heat flux causes an increase of the temperature of the water film, until the heat flux transported into the rock equals the heat flux from the cave air into the water film. 
If one knows the temperature $\mathrm{T}_{\mathrm{f}}$ of the water film, equal to that of the rock surface the amount of condensing water can be obtained by inserting Eq. 3 into Eq. 2, as

$$
F_{v}=\frac{D_{m}}{\varepsilon} \cdot\left(\frac{\Delta P}{\Delta T}\right) \cdot\left(\frac{T_{a}-T_{f}}{R T_{a}}\right) \cdot M=\frac{h_{v}}{\varepsilon}\left(T_{a}-T_{f}\right), \quad \mathrm{h}_{\mathrm{v}}=1.8 \cdot 10^{-5} \mathrm{gm}^{-1} \mathrm{~K}^{-1} \quad 7
$$

In a first approach, we reduce the problem to a simple one-dimensional setting. Fig. 2 shows this. An extended large cave is located at depth $\mathrm{Z}$ below the surface. We regard only the vertical heat flux towards the surface, thus reducing the problem to one dimension in $\mathrm{z}$-direction. This gives the following situation.

At $\mathrm{z}=0$ the temperature $\mathrm{T}_{0}$ is kept constant for $\mathrm{t}>0$. The cave roof at depth $\mathrm{Z}$ experiences a heat flow $\mathrm{F}_{\text {tot }}$ given by Eq. 6 .

A solution to this problem is given in Carslaw \& Jaeger (1959, p.125). We will not give the complete solution here. We extract what we need for further discussion:

The solution has a stationary part and the surface temperature of the rock at the cave wall becomes

$$
T_{f}^{\text {stat }}-T_{f i}=\frac{A}{1+A}\left(T_{a}-T_{f i}\right)
$$

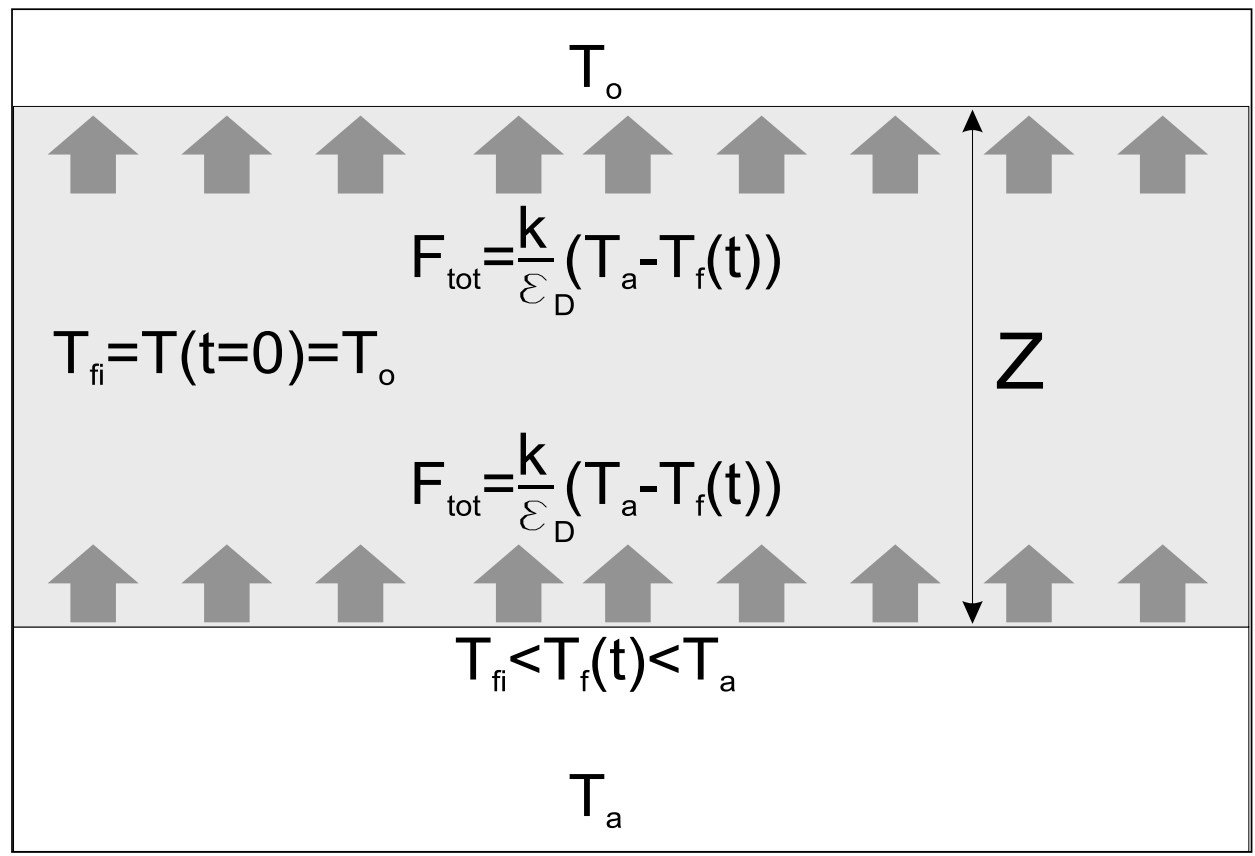

Fig. 2: A large extended hall at depth Z below ground is filled with air of 100\% humidity at constant temperature $T_{a}$. Due to heating from below $T_{a}$ is independent of time. Initially the temperature of the covering rock is the average annual temperature $T_{0}$ of the surface. As soon as heating by the cave air starts the wall temperature $T_{f}$ increases. Steady state is reached when the heat flow (gray arrows) to the cave ceiling equals that at the surface. 
where $\mathrm{A}$ is given by

$$
A=\frac{Z}{\varepsilon} \frac{k}{k_{r}}
$$

$\mathrm{k}_{\mathrm{r}}$ is the termal conductivity of the rock. $\mathrm{k}_{\mathrm{r}}=1.3 \mathrm{~W} /(\mathrm{m} \cdot \mathrm{K})$ for limestone and $0.5 \mathrm{~W} /(\mathrm{m} \cdot \mathrm{K})$ for gypsum. The stationary temperature $\mathrm{T}_{\mathrm{f}}^{\text {stat }}$ is reached after an exponential approach of the wall temperature with time constant $\tau_{\mathrm{s}}=\mathrm{Z}^{2} /\left(\beta^{2} \kappa\right)$, where $\kappa$ is the thermal diffusivity of the rock, $5.6 \cdot 10^{-7} \mathrm{~m}^{2} / \mathrm{s}$ for limestone and $3.6 \cdot 10^{-7} \mathrm{~m}^{2} / \mathrm{s}$ for gypsum. The value of $\beta$ is a function of $A$ by the relation $\beta \cot \beta-A$ $=0$, and is listed by Carslaw and Jaeger (1959). Its value ranges between $\pi / 2$ and $\pi$ from $A=0$ to $\mathrm{A}=\infty$. Initially, for times $\mathrm{t}<0.5$ years, however, the rise of surface temperature is much faster. It can be approximated by the solution, where $\mathrm{Z}$ is infinite, or in other words, where the rock in the cave is limited by a semi-infinite region of rock. In this case the surface temperature can be written (Carslaw \& Jaeger 1959).

$$
T_{f}-T_{f i}=\left(T_{a}-T_{f i}\right)\left(1-\exp \left(\frac{k^{2}}{k_{r}^{2} \varepsilon^{2}} \cdot \kappa t\right) \operatorname{erfc}\left(\frac{k}{k_{r} \varepsilon} \sqrt{\kappa t}\right)\right)
$$

$T_{f i}$ is the initial temperature of the rock. For our case with finite $\mathrm{Z}$, this solution is valid for $\mathrm{kt}<<\mathrm{Z}^{2}$, when the temperature front migrating into the rock has penetrated only a distance $d=\sqrt{\kappa t}$, very small against its thickness $\mathrm{Z}$.

Fig. 3 shows the exact temperature dependence for limestone with $Z=10 \mathrm{~m}, 30 \mathrm{~m}$, and $\infty$. It is of utmost importance to note that the initial rise of temperature is independent of $\mathrm{Z}$ and controlled by the quantity $\frac{k}{k_{r} \varepsilon} \sqrt{\kappa}$. For times $t>\left(\frac{k_{r} \varepsilon}{k}\right)^{2} \frac{9}{\kappa}$, Eq. 10 can be approximated by

$$
T_{f}(t)-T_{f i}=\left(T_{a}-T_{f i}\right)\left(1-\frac{1}{\sqrt{\pi \kappa}} \cdot \frac{k_{r} \varepsilon}{k} \frac{1}{\sqrt{t}}\right)
$$

The rates of condensing water for the the fast initial rise of temperature can now be obtained from Eqns. 7, 10 and 11

$$
F_{V}=\frac{D_{m}}{\varepsilon}\left(\frac{\Delta P}{\Delta T}\right) \frac{M}{R T_{a}} \cdot\left(T_{a}-T_{f_{i}}\right) \cdot\left(\exp \left(\frac{k^{2}}{\varepsilon^{2} k_{r}^{2}} \kappa t\right) \operatorname{erfc}\left(\frac{k}{k_{r} \varepsilon} \sqrt{\kappa t}\right)\right)
$$

For times $t>\left(\frac{k_{r} \varepsilon}{k}\right)^{2} \frac{9}{\kappa}$, a slow decline of the temperature difference $\mathrm{T}_{\mathrm{a}}-\mathrm{T}_{\mathrm{f}}(\mathrm{t})$ towards stationary state yields rates

$$
F_{V}^{\text {slow }}=D_{m}\left(\frac{\Delta P}{\Delta T}\right) \frac{M}{R T_{a}}\left(\frac{1}{\sqrt{\pi \kappa}} \frac{k_{r}}{k} \frac{1}{\sqrt{t}}\right) \cdot\left(T_{a}-T_{f i}\right) \quad\left[\mathrm{gm}^{-2} \mathrm{~s}^{-1}\right]
$$

It is important to note that this is independent of $\varepsilon$. The minimum rate of condensation is reached at stationary state after time $5 \tau_{\mathrm{s}}$. 

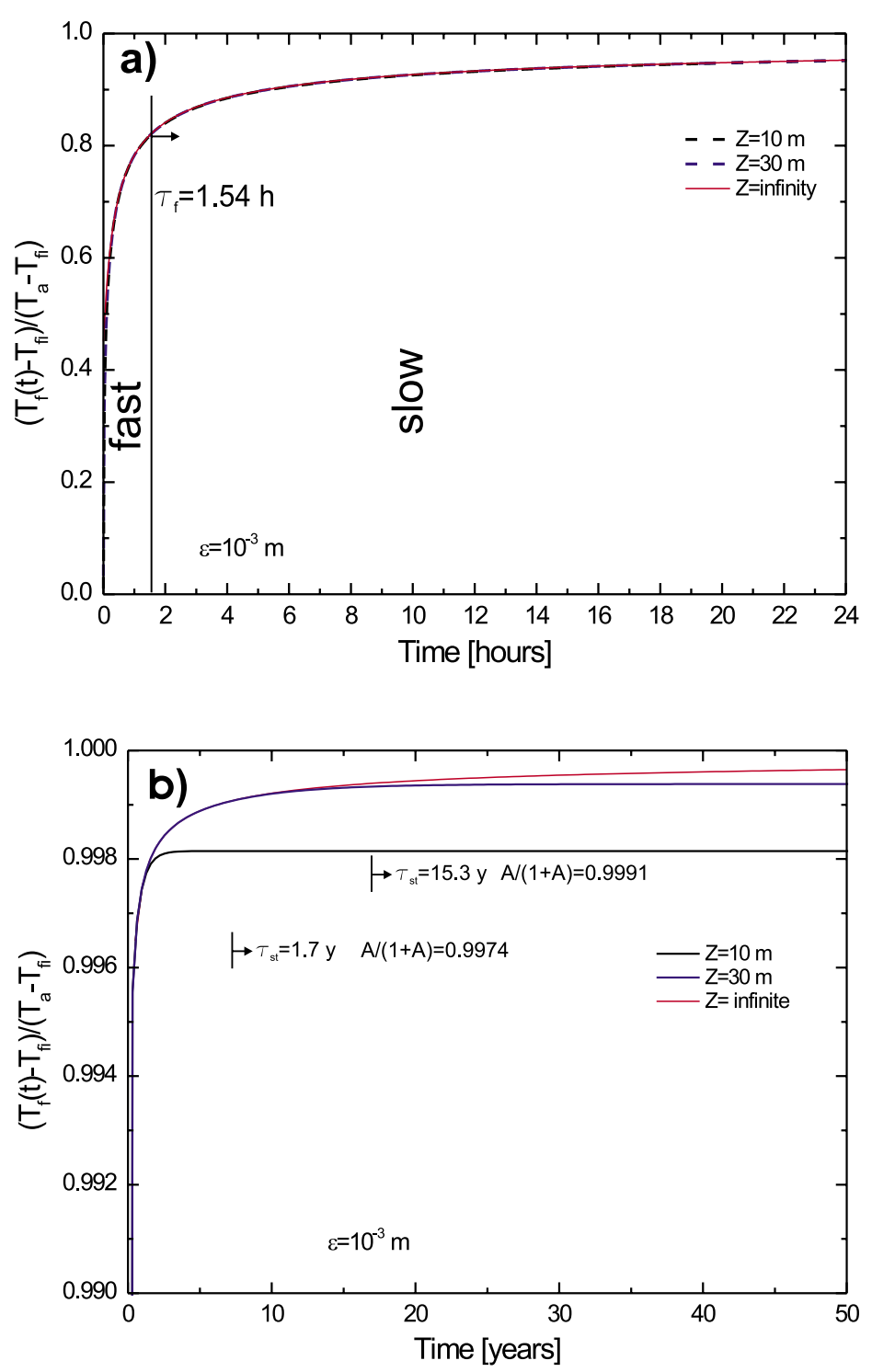

Fig. 3: Time dependence of the temperature difference $T_{a}-T_{f}(t)$ normalized to initial temperature difference $T_{a}-T_{f i}$ a) Results for the first 24 hours. $\left.b\right)$ Results for long times. Until time $\tau_{f}$ normalised temperature difference rise to 0.84. After this time it rises according to Eq.11 until finally it approaches a stationary state after time $5 \tau_{s}$. The black curve is calculated with $\varepsilon=10^{-3} \mathrm{~m}$ and $Z=10 \mathrm{~m}$ and the blue one for $Z=30$ $m$. The red curve is calculated for $Z=\infty$, a semi infinite medium. Note the coincidence of the curves in early evolution. The normalized temperature difference in the stationary state is given by $A /(A+1)$. 


$$
F_{V}^{s t a c}=\frac{D_{m}}{\varepsilon}\left(\frac{\Delta P}{\Delta T}\right) \frac{M}{R T_{a}} \cdot \frac{A}{1+A}\left(T_{a}-T_{f i}\right)=1.8 \cdot 10^{-5} \frac{T_{a}-T_{f i}}{\varepsilon+\frac{k}{k_{r}} Z} \quad\left[\mathrm{gm}^{-2} \mathrm{~s}^{-1}\right]
$$

Note that for $\mathrm{Z} \gg>\mathrm{k}_{\mathrm{r}} \varepsilon / \mathrm{k}$ the condensation rate becomes independent of $\varepsilon$. This is true for $\mathrm{Z}$ $\geq 10 \mathrm{~m}$ and $\varepsilon<10^{-3} \mathrm{~m}$.

The decay time towards this stationary state is given by

$$
\tau_{s} \approx \frac{Z^{2}}{\beta^{2} \kappa} \quad[\mathrm{s}]
$$

At a depth of $100 \mathrm{~m}$ this is about 127 years, a short time with respect to the time scales of cave evolution.

Fig. $4 \mathrm{a}$ shows the rates of condensation for $\mathrm{Z}=100 \mathrm{~m}$ and various values of $\varepsilon$. Fig. $4 \mathrm{~b}$ depicts the amount of condensed water after time $t$, which is obtained by integration of the curves in Fig. $4 \mathrm{a}$.

In summary, the following picture emerges. For times smaller than $0.5 \tau_{\mathrm{s}}$ the temperature increase of the cave wall can be well approximated by Eqns.10 and 11. Later, for times $t>5 \tau_{\mathrm{s}}$ the stationary state is reached by an exponential approach and the temperature becomes constant.

Fig. 3 shows this for $\varepsilon=0.001 \mathrm{~m}$. The black line shows $\left(\mathrm{T}_{\mathrm{f}}-\mathrm{T}_{\mathrm{f}}\right) /\left(\mathrm{T}_{\mathrm{a}}-\mathrm{T}_{\mathrm{fi}}\right)$ for a depth of $\mathrm{Z}=10$ $\mathrm{m}$, the blue line gives the temperature rise for $\mathrm{Z}=30 \mathrm{~m}$. The red curve shows the temperature for the semi-infinite plane with $\mathrm{Z}=\infty$.

\section{CONDENSATION IN STATIONARY BOUNDARY CONDITIONS}

Our one-dimensional model is idealistic because it requires a cave chamber with horizontal dimension, one order of magnitude larger than its height.

Other geometries are more suitable, e.g. a spherical room with diameter $\mathrm{D}_{\mathrm{s}}$ or a cylindrical conduit of diameter $\mathrm{D}_{\mathrm{c}}$ and length $\mathrm{L}$, both buried at depth $\mathrm{Z}$. These are shown in Fig. 5a-c. For such situations analytical results are not available. But the general behavior is similar to the idealistic one-dimensional case, and it is possible to obtain the temperature at stationary state, reached after $t>5 \tau$, by the theory of conduction shape factors (Incropera \& DeWitt 2002). At stationary state, the wall of the rock is at temperature $\mathrm{T}_{\mathrm{f}}^{\text {stat }}$ and the surface temperature at $\mathrm{z}=0$ is $\mathrm{T}_{0}$. See Fig. 2. The total amount of heat flowing from the conduit to the surface is then given by

$$
Q_{r}=S \cdot k_{r}\left(T_{f}^{\text {stat }}-T_{o}\right) \quad[\mathrm{W}]
$$

where $\mathrm{S}[\mathrm{m}]$ is the shape factor. The expressions for some shape factors are given in Table 1 .

\begin{tabular}{|c|c|c|}
\hline System & Restriction & Shape factor \\
\hline $\begin{array}{c}\text { Sphere in a semi infinite } \\
\text { medium (Fig. 5a) }\end{array}$ & $\mathrm{z}>\mathrm{D} / 2$ & $\frac{2 \pi D}{1-D / 4 Z}$ \\
\hline $\begin{array}{c}\text { Cylinder in a semi infinite } \\
\text { medium (Fig. 5b) }\end{array}$ & $\mathrm{L}>>\mathrm{D}$ & $\frac{2 \pi L}{\ln (4 Z / D)}$ \\
\hline Slab (Fig. 5c) & $\mathrm{z}>3 \mathrm{D} / 2$ & $\sigma / \mathrm{Z}$ \\
\hline
\end{tabular}

Table 1: Shape factors for some typical geometries as shown in Figs. 5a-c. 

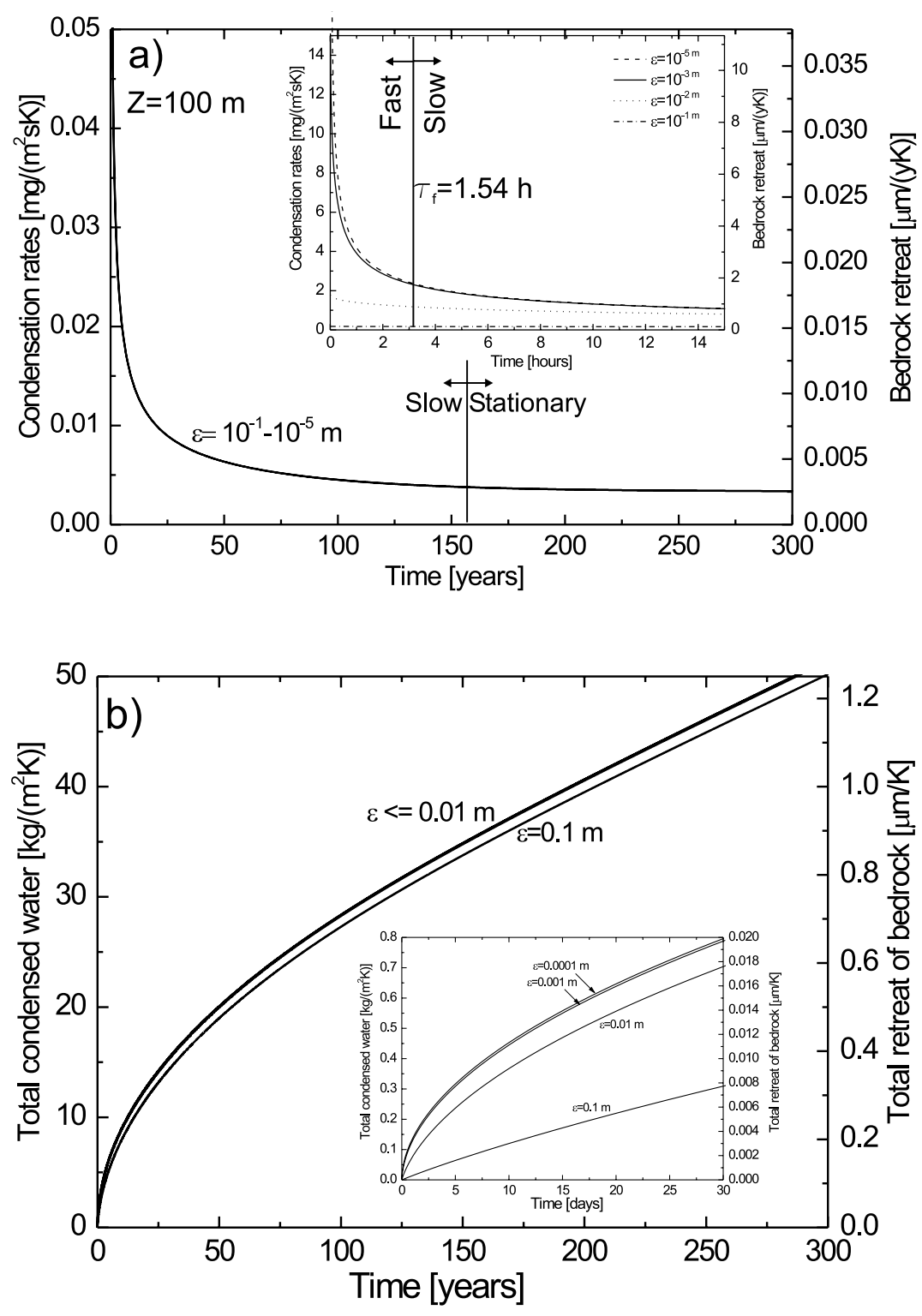

Fig. 4: a) Rates of condensation and retreat of bedrock as function of time divided by the initial temperature difference $T_{a}-T_{f}$. Values of $\varepsilon$ are written at the curves. Note that for large times all curves coincide, i.e the rates become independent of $\varepsilon$. $b$ ) Amount of condensed water per $m^{2}$ and $K$ of temperature difference and total retreat of bedrock for the cases of Fig. 4a. Note that although the variation of $\varepsilon$ covers two orders of magnitude, the amount of condensed water only weakly depends on $\varepsilon$. 
The total heat transferred to the wall of the cave is

$$
Q_{w}=\sigma \cdot \frac{k}{\varepsilon}\left(T_{a}-T_{f}^{\text {stat }}\right)
$$

where $\sigma$ is the surface area of the cave.

Conservation of energy requires $\mathrm{Q}_{\mathrm{w}}=\mathrm{Q}_{\mathrm{r}}$. Therefore one finds

$$
\left(T_{a}-T_{f}^{\text {stat }}\right)=\frac{1}{1+\frac{k \cdot \sigma}{k_{r} \cdot \varepsilon \cdot S}}\left(T_{a}-T_{o}\right)
$$

From this the rate of condensed water can be calculated by use of Eq. 7 .

Fig. 5d shows these rates per degree $\mathrm{K}$ for circular cave rooms and cylindrical conduits, buried at depth Z. Note that for $\varepsilon<<0.038 \sigma / \mathrm{S}$ the rates are independent of $\varepsilon$, which is true for all practical applications.

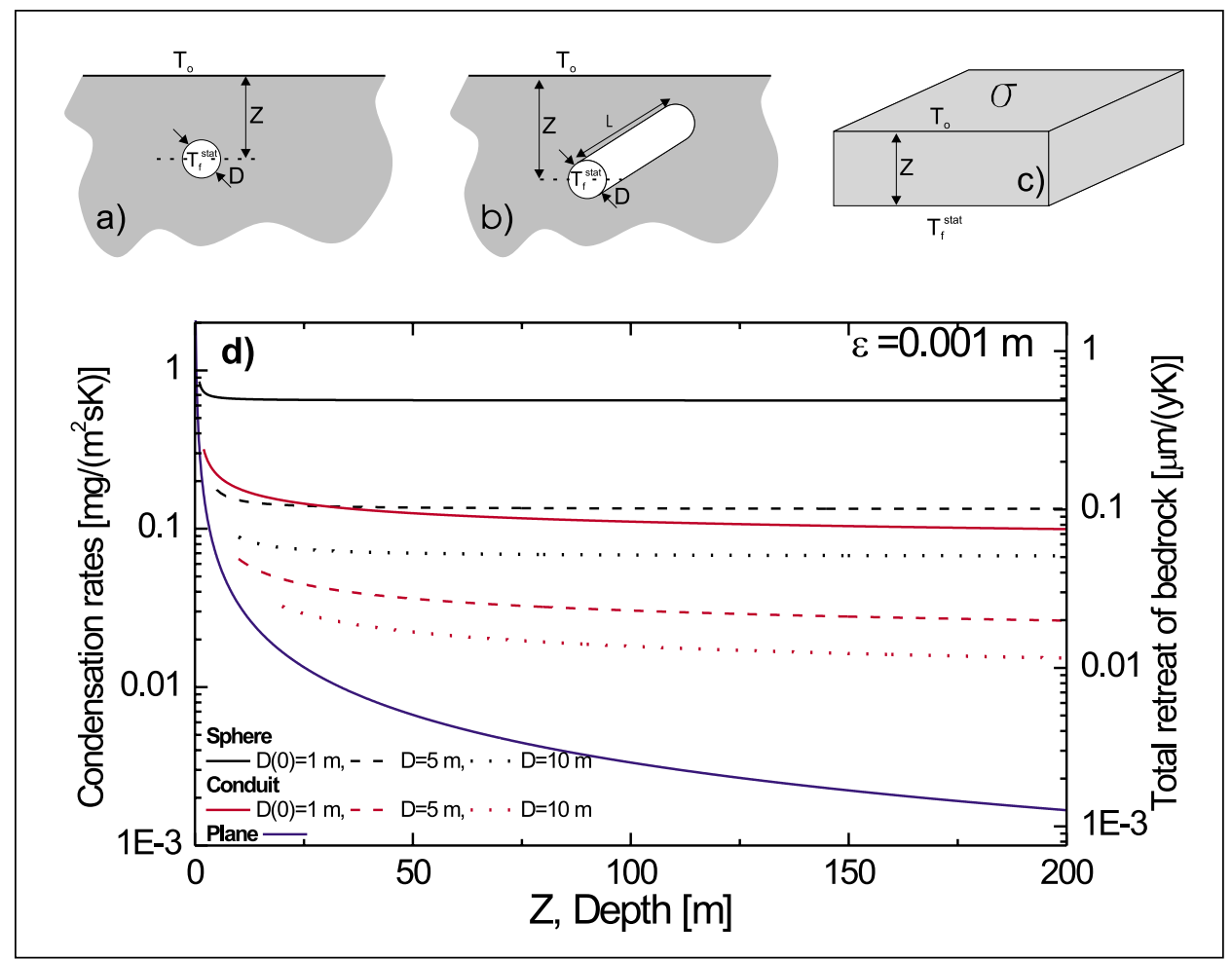

Fig. 5: a-c) Geometrical configurations for the shape factors in Table 1.d) Condensation rates and retreat of bedrock in the stationary state in dependence on depth $Z$ for spheres and cylindrical conduits with various diameters. $D(0)$ is the initial diameter. The blue curve represents one dimensional scenario (slab with thickness Z) of Fig. 5c. See also Fig. 2. 
Spheres show the highest condensation rates, almost independent of their depth $\mathrm{Z}$ below ground, but dependent on their diameter $\mathrm{D}_{\mathrm{s}}$. As we will show in the appendix, films of water running down rock-walls of gypsum or limestone can be regarded as saturated with respect to gypsum or limestone. Therefore at a $\mathrm{p}_{\mathrm{CO} 2}=0.00035 \mathrm{~atm}$, for limestone with saturation concentration of $60 \mathrm{mg} / \mathrm{L}, 1 \mathrm{~g} / \mathrm{m}$ ${ }^{2} \mathrm{~S}^{-1}$ of condensed water corresponds to retreat of rock by $7.5 \cdot 10^{-4} \mathrm{~m} /$ year using $\rho=2500 \mathrm{~kg} / \mathrm{m}^{3}$ as density of a slightly porous limestone. For gypsum with a saturation concentration of $2.5 \mathrm{~g} / \mathrm{L}$ (independent on $\mathrm{p}_{\mathrm{CO} 2}$ ) and density $2300 \mathrm{~kg} / \mathrm{m}^{3}$, the retreat of rock can be approximately obtained by multiplying the values for limestone $\left(\mathrm{p}_{\mathrm{CO} 2}=0.00035 \mathrm{~atm}\right)$ by a factor of 50 .

Now we assume the following situation. A spherical cave of initial diameter $\mathrm{D}_{\mathrm{s}}(0)$ is invaded by geothermal waters with temperature $\mathrm{T}_{\mathrm{a}}$, higher than the initial rock temperature $\mathrm{T}_{\mathrm{fi}}$. Water evaporates from a lake, stable for long times. We assume the cave $100 \mathrm{~m}$ below ground. Then after about 100 years the stationary state is attained.

The change of diameter $\mathrm{D}_{\mathrm{s}}$ is then approximated quite accurately by

$$
\frac{d D_{s}}{d t} \approx 2 \times 1.8 \cdot 10^{-5} \times 7.5 \cdot 10^{-4} \times \frac{1}{\varepsilon+\frac{k}{k_{r}} \cdot \frac{D_{s}}{2}}\left(T_{a}-T_{f i}\right) \quad[\mathrm{m} / \text { year }]
$$

For limestone one gets

$$
\frac{d D_{s}}{d t} \approx 1 \cdot 10^{-6} \cdot \frac{1}{D_{s}} \cdot\left(T_{a}-T_{f i}\right) \quad[\mathrm{m} / \text { year }]
$$

Note that growth rates decrease with $1 / \mathrm{D}_{\mathrm{S}}$.

Integration of Eq. 20 yields

$$
D_{s}^{2}(t)-D_{s}^{2}(0) \approx 2 \cdot 10^{-6} \cdot t \cdot\left(T_{a}-T_{f i}\right)
$$

where $t$ is in years. A cave with initial diameter of $1 \mathrm{~m}$ evolves into a cupola of $10 \mathrm{~m}$ diameter independent of its depth $\mathrm{Z}$ for $\mathrm{D} /(4 \mathrm{Z})>10$ in $5 \cdot 10^{7}$ years for $\mathrm{T}_{\mathrm{a}}-\mathrm{T}_{\mathrm{fi}}=1 \mathrm{~K}$.

A sphere with initial diameter of $0.1 \mathrm{~m}$ needs, however, only 530000 years to reach a diameter of $1 \mathrm{~m}$ for $\mathrm{T}_{\mathrm{a}}-\mathrm{T}_{\mathrm{fi}}=1 \mathrm{~K}$.

For a cylindrical conduit buried at depth $\mathrm{Z}$,

$$
\frac{d D_{C}}{d t} \approx 1 \cdot 10^{-6} \cdot\left(T_{a}-T_{f i}\right) \frac{1}{D_{C} \ln \frac{4 Z}{D_{C}}} \quad[\mathrm{~m} / \text { year }]
$$

which can be integrated

$$
-D^{2}(t)\left\{\ln \frac{D(t)}{4 z}-\frac{h}{2}\right\}+D(0)\left\{\ln \frac{D(0)}{4 z}-\frac{1}{2}\right\}=2 \cdot 10^{-6} \times t \times\left(T_{a}-T_{f i}\right) \quad[\mathrm{m} / \text { year }]
$$

For $\mathrm{Z}=100 \mathrm{~m}$ growth from initially $1 \mathrm{~m}$ to $10 \mathrm{~m}$ takes $2 \cdot 10^{8}$ years for $\mathrm{T}_{\mathrm{a}}-\mathrm{T}_{\mathrm{fi}}=1 \mathrm{~K}$, and correspondingly $2 \cdot 10^{7}$ years if the temperature difference is $10 \mathrm{~K}$.

Fig. 6 shows growth times for spheres and cylindrical conduits at various depths nd with various diameters.

A final statement must be given. In this section we have assumed that temperature difference between the cave and the surface and 100\% relative humidity of the cave air are independent of time. 
This may be the case when hydrothermal waters form open surfaces, from which evaporating waters condense at cave walls, delivering a constant flow of water in equilibrium with the $\mathrm{p}_{\mathrm{CO} 2}$ of the cave atmosphere. These waters attain equilibrium with respect to the soluble rock, either limestone or gypsum (see appendix). The saturation concentration for limestone is $c_{e q}=60 \mathrm{mg} / \mathrm{L} \cdot \sqrt[3]{p_{c o_{2}} / 3.5 \cdot 10^{-4}}$ $\mathrm{mg} / \mathrm{L}$, where $\mathrm{p}_{\mathrm{CO} 2}$ is the partial pressure of $\mathrm{CO}_{2}$ in the cave atmosphere, measured in atm.

Our findings of Eq. 21 explain the existence of spherical niches and cupola in caves of Hungary (Muller, 1974) in Italy, (Cigna \& Forti 1986), and in hypogenetic caves in France (Audra et al. 2002). Sarbu \& Lascu (1997) report on the measurements of active condensation corrosion in Movile Cave, Romania.

Mostly in nature external boundary conditions are not constant in time. Annual fluctuations in the temperature of the cave air might occur when a river flows into a cave, with warm water in summer, which evaporates and condenses at the cave walls. In the winter time, however, the water is colder than the temperature at the cave walls and condensation stops. In view, that to attain stationary state under time independent boundary conditions takes several years, such cases cannot be described by the considerations above.

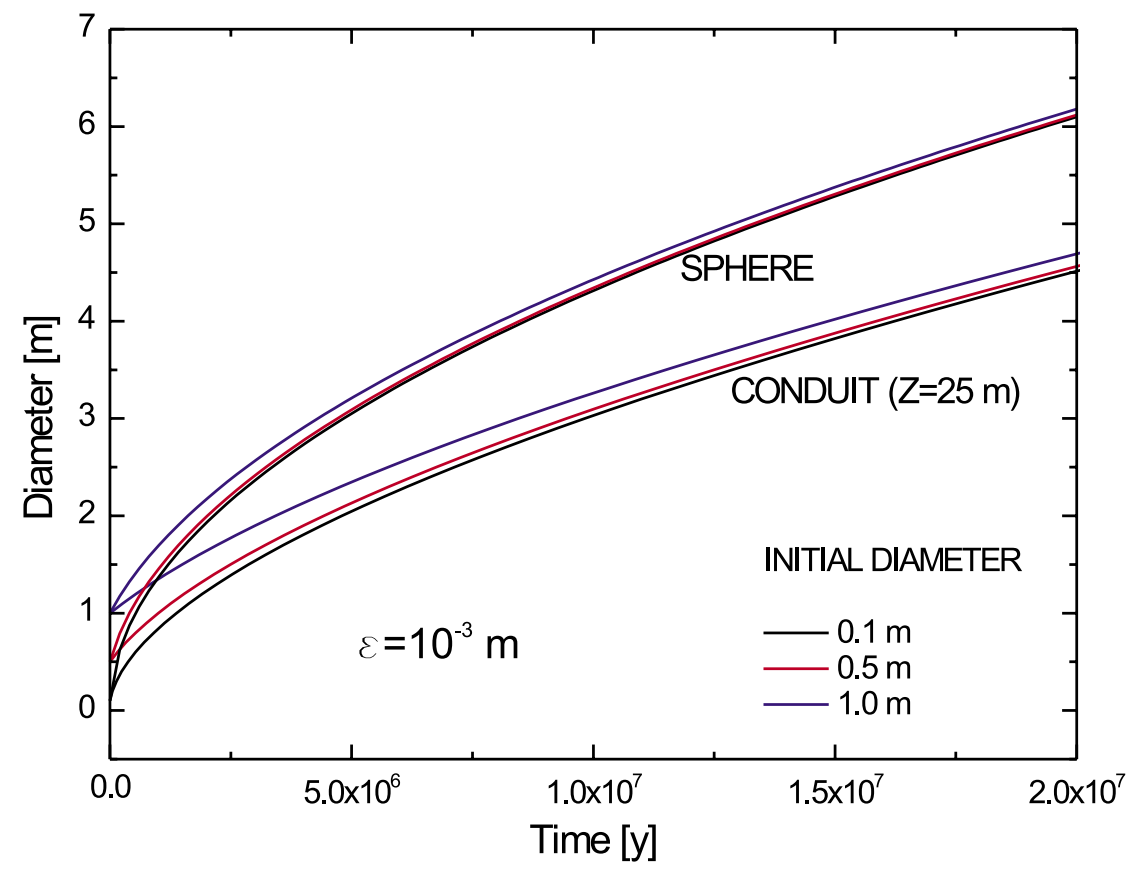

Fig. 6: Diameters of spheres and cylindrical conduits with initial diameter of 0.1, 0.5 and $1 \mathrm{~m}$ at depth of $25 \mathrm{~m}$ as a function of time. The curves are calculated from equations 21 and 23, respectively. 


\section{CONDENSATION AT PERIODIC BOUNDARY CONDITIONS}

As already shown Fig. 4a presents the time dependence of the rate of condensing water. A first rapid decline until time $t=\tau_{f}$ (see Eq.12)

$$
\tau_{f}=9 \cdot\left(\frac{k_{r} \varepsilon}{k}\right)^{2} \frac{1}{\kappa}
$$

is followed by a slow decline (see Eq. 13) exhibiting a $\mathrm{t}^{-1 / 2}$ - time dependence.

After the time $\mathrm{t}=5 \tau_{\mathrm{s}}$ stationary state is attained (see Eq. 15). Note that the time to reach stationary state is controlled by the depth $\mathrm{Z}$ of the cave below ground and the thermal diffusivity $\kappa$, whereas the decline toward stationary state depends solely on the thermal properties $\kappa, \mathrm{k}$, and $\mathrm{k}_{\mathrm{r}}$ and is independent of the depth Z. (See Eq.13).

Variations of the cave temperature can be caused by diurnal fluctuations when warm humid air flows through the cave during day time, but during the night cold dry air enters. If the initial temperature of the rock is $\mathrm{T}_{\mathrm{fi}}$ and the temperature of the cave air with a humidity of $100 \%$, is $\mathrm{T}_{\mathrm{a}}$ within the time $t=9\left(k_{r} \varepsilon / k\right)^{2} / K$ the temperature $T_{f}$ of the rock has increased such that $T_{a}-T_{f}=0.18\left(T_{a}-T_{f i}\right)$. From then on $\mathrm{T}_{\mathrm{a}}-\mathrm{T}_{\mathrm{f}}$ is given by Eq. 13. Note that for $\varepsilon=0.001 \mathrm{~m}, \mathrm{t}=9\left(\mathrm{k}_{\mathrm{r}} \varepsilon / \mathrm{k}\right)^{2} / \mathrm{\kappa}=5.5 \cdot 10^{3} \mathrm{~s}$ whereas the equilibration time $5 \tau_{\mathrm{s}}=9 \cdot 10^{5} \mathrm{~s}$ for $\mathrm{Z}=1 \mathrm{~m}$. Therefore at depths $\mathrm{Z}>1 \mathrm{~m}$ daily variations in $\mathrm{T}_{\mathrm{a}}$ cause temperature changes of the rock, which are governed by the entity $\left(\mathrm{k}_{\mathrm{r}} / \mathrm{k}\right)$.

When cold air, at temperature $T_{n}$ colder than the actual temperature $T_{f}$ at the cave walls enters into the cave during the night, condensation stops.

Two possibilities can be envisaged. The water, which has condensed during day time evaporates during the night. In this case, in a first approximation, the temperature of the cave wall drops towards the temperature of the cold air in about the same time as is needed to approach to the temperature of the warm air during day time. This is shown by Fig. 7a. As a result calcium carbonate dissolved during the day, will be precipitated during the night, and this process disintegrates the texture of the rock, leaving a weathered rind of corroded material (Auler $\&$ Smart 2004). For $\varepsilon=0.001 \mathrm{~m}$, the amount of water condensing within 10 hours is about $100 \mathrm{~g} /\left(\mathrm{m}^{2} \mathrm{~K}\right)$ as can be obtained by integrating Eqs. 12 and 13. See Fig. 4b, which shows the amount of condensed water per square meter as a function of time for various values of $\varepsilon$ and a temperature difference $\mathrm{T}_{\mathrm{a}}-\mathrm{T}_{\mathrm{fi}}$ of $1 \mathrm{~K}$.

In the other extreme, when the condensed water flows sufficiently fast from the rock, evaporation is excluded. Heat transfer from the rock through the boundary layer is affected only by thermal conduction. The heat transfer coefficient $\mathrm{k}_{\mathrm{a}} / \varepsilon_{\mathrm{T}}$ (see Eq.5) is therefore lower by a factor of $2.7 \mathrm{com}$ pared to that, when condensation is present (see Eq. 6).

The time dependence of cooling or heating is given by the dimensionless variable $\mathrm{k} \cdot(\kappa \mathrm{t})^{1 / 2} /\left(\mathrm{k}_{\mathrm{r}} \varepsilon\right)$. With $\mathrm{k}$ lower by a factor of 2.7 cooling takes a time, longer by a factor of 7 than heating. Therefore during the cooling period the wall of the rock cools down slower. This way, after several cycles a stationary amplitude is established with constant temperature differences of the rock wall, and condensation rates are reduced. Fig. $7 \mathrm{~b}$ shows this schematic concept. These two scenarios are extremes. Depending on the relative humidity of the air during the day and during the night, rates will be between these two extreme limits. We will discuss this latter in detail.

Seasonal variations can be caused when warm water from the surface enters into the cave in summer time and condensation takes place, whereas in winter time, when cold water flows into the 

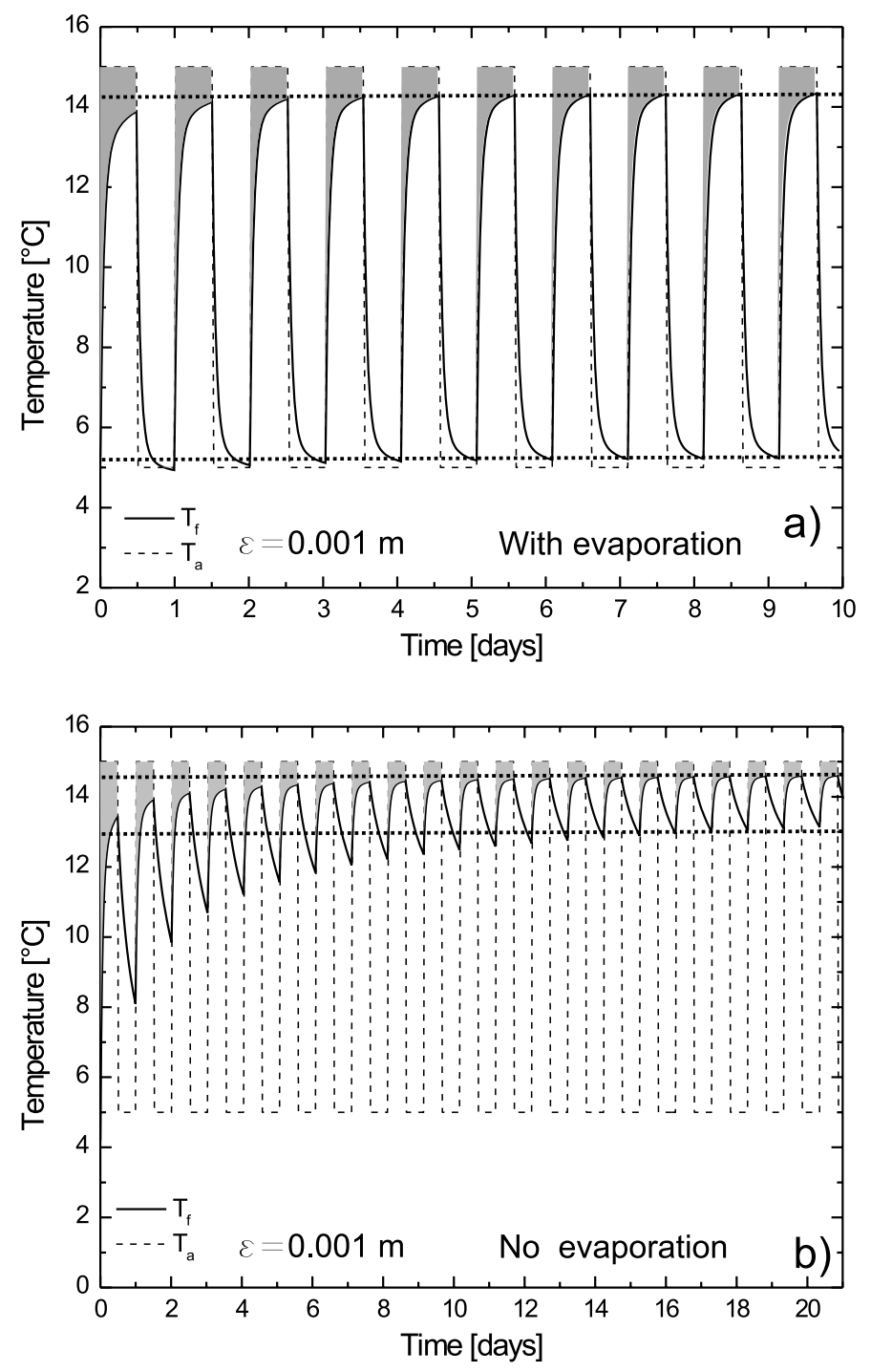

Fig. 7: Wall temperature for diurnal temperature variations of $T_{a}$ in the cave. For simplicity an abrupt change between day temperature $T_{\text {day }}$ and lower night temperature $T_{\text {night }}$ is assumed. The initial temperature of the cave wall $T_{f}<T_{\text {night }}$ a) Water accumulated at the surface by condensation during day time evaporates during night time. Rates of heating during the day and cooling during the night are almost equal. Average rates of condensation are high. b) Condensation during day time, but evaporation during the night is absent. Therefore the of cooling rate is only about 15\% of the heating rate during daytime. A steady state with less average condensation is reached after several cycles. Note that the shaded areas give a measure of condensed water. The two parallel dotted lines present upper and lower temperatures at steady state. 
cave, condensation stops. For most cases of interest, with caves deeper than $5 \mathrm{~m}$, the time to reach a stationary state is longer than 2 years. The amount of water condensing during the summer period can be obtained by integration of Eqs. 11, 12. See also Fig. 4. It can be approximated by

$$
Q=0.5\left(T_{a}-T_{f i}\right)\left[\sqrt{t_{C}}+20\right] \quad\left[\mathrm{g} / \mathrm{m}^{2}\right]
$$

for $t_{c} \geq 4 \cdot 10^{4} s$, where $t_{c}$ is the period of condensation in seconds. For $t_{c}=8.4 \cdot 10^{6} \mathrm{~s} \approx 100$ days this corresponds to about $1500 \mathrm{~g} /\left(\mathrm{m}^{2} \mathrm{~K}\right)$, equivalent to a retreat of cave wall by $3.5 \cdot 10^{-8} \mathrm{~m} /(\mathrm{yK})$. During winter time condensation stops and the cave walls have sufficient time to cool to low temperatures. Then in summer condensation starts again. Note that so far all calculations of retreat of rock are based on the assumption that $\mathrm{p}_{\mathrm{CO} 2}$ in the cave is at atmospheric level with $3.5 \cdot 10^{-4} \mathrm{~atm}$, and that the solution flowing off the wall has attained saturation with respect to calcite. For elevated values of $\mathrm{p}_{\mathrm{CO} 2}$ in the cave all numbers given so far must be multiplied by $\left(\mathrm{p}_{\mathrm{CO} 2} / 0.00035\right)^{1 / 3}$ to account for elevated pressure $\mathrm{p}_{\mathrm{CO} 2}$ in the cave.

\section{CONDENSATION CORROSION ON SPELEOTHEMS}

Many researchers have observed features of surface corrosion on speleothems, which they interpret as a results of condensation corrosion (Auler \& Smart 2004; Dublyansky \& Dublyansky 2000; Tarhule-Lips \& Ford 1998). In this section the physical background is discussed.

Fig. 8 depicts the thermal boundary conditions for a stalagmite. At the outer surface heat flux is given by the action of condensation. At the base heat is transferred into the colder base rock. As can be calculated from Fig. 8 this heat flow is negligible. The decay time which is needed in such a case to approach thermal equilibrium (Luikov 1968), page 217) is $\tau_{\text {Stal }}=\mathrm{D} /\left(4 \mu_{1}{ }^{2} \kappa\right)$, where $\mu_{1}$ is the first root of the equation $\operatorname{tg} \mu=\frac{2 \varepsilon k_{r}}{D k} \cdot \mu$. For $\mathrm{D}=1 \mathrm{~m}, \mu_{1}$ is $\pi^{2} / 4$ and $\tau_{\text {Stal }}=2$ days.

When thermal equilibrium is reached after $5 \tau_{\mathrm{s}}$ condensation stops. Therefore to keep condensation active, diurnal variations in cave temperature are necessary. When the equilibration time $5 \tau_{\text {Stal }}$ is longer than a day, and when during the night evaporation takes place a stationary state with high average rates is reached after some days. Lower rates are effective when evaporation is excluded during the night.

We restrict to a more simple approximation. We assume stalagmites with diameters less than $0.3 \mathrm{~m}$ corresponding to $\tau_{\text {Stal }}=0.2$ day. In this case the stalagmite practically reaches temperature $\mathrm{T}_{\mathrm{a}}$ during day time. Even, if no evaporation is present during the night, the time to cool down is longer only a factor of 2 . This results from the dependence of the root $\mu$ on the heat transfer coefficient $\mathrm{k}$ (Luikov 1968, page 217).

The maximal amount of condensing water during one day can be estimated from conservation of energy. The total heat transferred to the stalagmite must be equal to the increase of internal energy due to heating from the initial temperature $\mathrm{T}_{\mathrm{i}}$ at $\mathrm{t}=0$ to the stationary temperature $\mathrm{T}_{\mathrm{a}}$.

According to Eqs. 4 and 5 about $70 \%$ of the total heat transfer results from condensation. Therefore to a sufficiently good approximation one has

$$
q_{C} \cdot M_{C}=0.7 \cdot c_{p} \cdot M_{s} \cdot \Delta T
$$


where $\mathrm{M}_{\mathrm{c}}$ is the mass of condensed water during 1 day, $\mathrm{c}_{\mathrm{p}}$ is the specific heat of limestone $(0.88$ $\mathrm{kJ} / \mathrm{kg} \mathrm{K})$ and $\Delta \mathrm{T}$ is the change of temperature until the end of heating. It is close to $\Delta \mathrm{T}=\left(\mathrm{T}_{\text {day }}-\mathrm{T}_{\text {night }}\right)$. $\mathrm{M}_{\mathrm{s}}$ is the mass of the stalagmite with diameter $\mathrm{D}$ and length $\mathrm{L}$.

From Eq. 26 one finds the amount of water which condenses during one period of heating. Dividing this by the surface area of the stalagmite gives the amount of water condensed per $\mathrm{m}^{2}$ during the heating period as

$$
F_{0}=\frac{0.7}{4} \cdot \frac{c_{p}}{q_{C}} \rho D \Delta T \approx 0.17 D \Delta T \quad\left[\mathrm{~kg} / \mathrm{m}^{2}\right]
$$

this corresponds to retreat of surface by

$$
\begin{aligned}
& \delta_{c}=3.8 \cdot 10^{-9} D \Delta T \quad[\mathrm{~m} / \text { day }] \\
& \text { or } \\
& \delta_{y}=1.4 \cdot 10^{-6} D \Delta T \quad[\mathrm{~m} / \text { year }]
\end{aligned}
$$

for $\mathrm{D}<0.3 \mathrm{~m}$. Note that for compact stalagmites we use the density of $2700 \mathrm{~kg} / \mathrm{m}^{3}$.

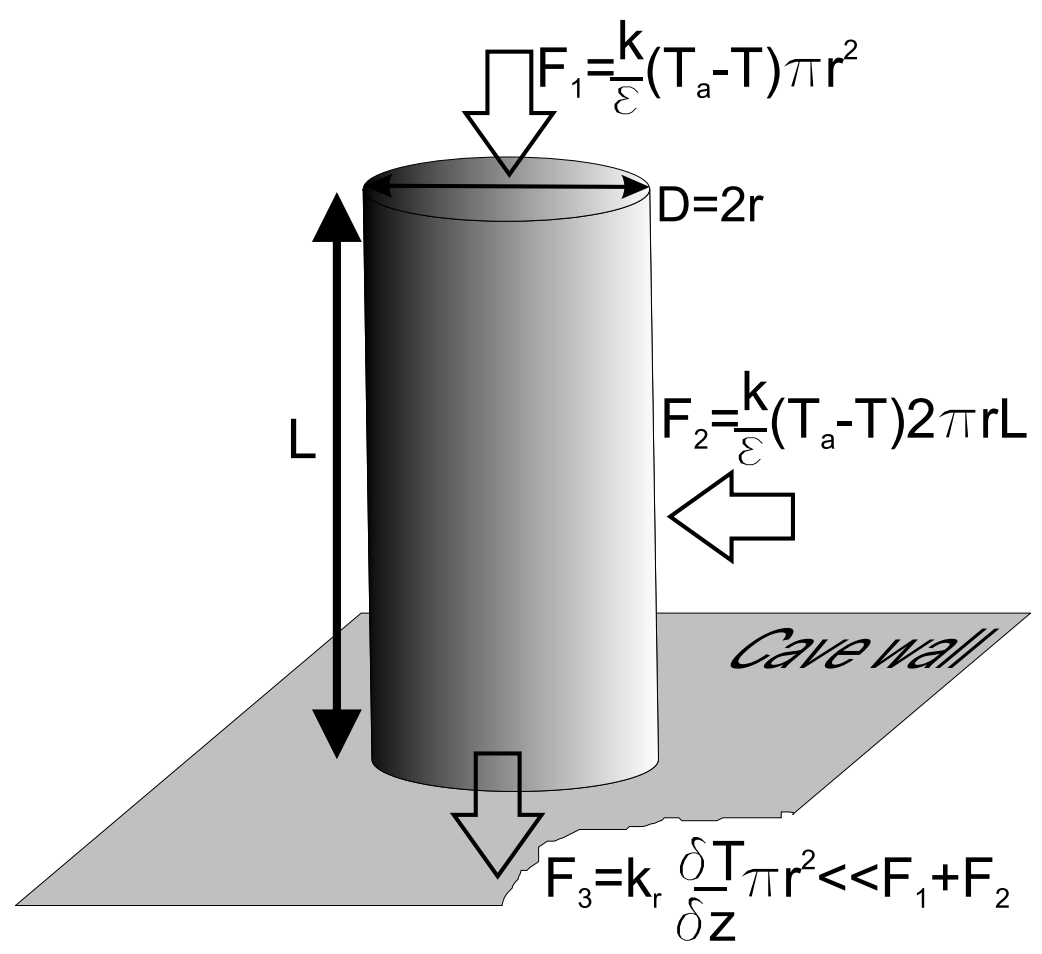

Fig. 8: Heat rates transferred via corresponding surface of a stalagmite with length $L$ and radius $r$. $k=0.07 \mathrm{Wm}^{-1} \mathrm{~K}^{-1}, k r=1.3 \mathrm{Wm}^{-1} \mathrm{~K}^{-1}$. Even at a temperature gradient of $10 \mathrm{~K} / \mathrm{m}$ at the base, $F 3<<F 1+F 2$, as long $(\mathrm{Ta}-\mathrm{T})>0.1 \mathrm{~K} . \mathrm{T}$ is the surface temperature of the stalagmite. 
For larger diameter $\mathrm{D}>1 \mathrm{~m}$ the equilibration times for heating and cooling are longer than 5 days. If such a stalagmite experiences condensational heating with equilibration time $\tau_{1}=\tau_{\text {Stal }}$ during the time $t_{1}$ and cooling with equilibration time $\tau_{2}$, during the time $t_{2}$ after several cycles the maximum temperature and the minimum temperature become independent on time.

The temperature difference $\mathrm{T}_{\max }-\mathrm{T}_{\min }$ can be estimated in the following way. During heating the temperature $\mathrm{T}_{\mathrm{h}}(\mathrm{t})$ of stalagmite to an acceptable approximation is given by

$$
\left(T_{h}(t)-T_{\min }\right)=\left(T_{h}-T_{\min }\right)\left(1-\exp \left(-\frac{t}{\tau_{1}}\right)\right)
$$

where $\mathrm{T}_{\min }$ is the minimum temperature at the end of prior cooling, and $\mathrm{T}_{\mathrm{h}}$ is the temperature of the cave air during heating. For the cooling period $t_{2}$ with equilibration time $\tau_{2}$ the temperature $T_{c}$ of the stalagmite is given by

$$
\left(T_{c}(t)-T_{c}\right)=\left(T_{\max }-T_{c}\right) \exp \left(-\frac{t}{\tau_{2}}\right)
$$

where $\mathrm{T}_{\mathrm{c}}$ is the air temperature in cave during cooling and $\mathrm{T}_{\max }$ the temperature of the stalagmite at the end of prior heating. From 29 and 30 we get

$$
\begin{aligned}
& T_{\text {max }}-T_{\text {min }}=\left(T_{h}-T_{\min }\right)\left(1-\exp \left(-t_{1} / \tau_{1}\right)\right) \\
& T_{\text {min }}-T_{c}=\left(T_{\max }-T_{c}\right) \exp \left(-t_{2} / \tau_{1}\right)
\end{aligned}
$$

Solving this equation one finds

$$
\Delta T=T_{\max }-T_{\min }=\left(T_{h}-T_{c}\right) \frac{\left(1-\exp \left(-t_{1} / \tau_{1}\right)\right)\left(1-\exp \left(-t_{2} / \tau_{2}\right)\right)}{1-\exp \left(-t_{1} / \tau_{1}\right) \exp \left(-t_{2} / \tau_{2}\right)}
$$

To estimate the amount of condensation corrosion, this value of $\Delta \mathrm{T}$ must be used in Eq. 28 .

$\Delta \mathrm{T}$ in Eq. 32 becomes $0.25\left(T_{h}-T_{c}\right)$ for $\frac{t_{1}}{\tau_{1}}=\frac{t_{2}}{\tau_{2}}=0.5$ and $0.12\left(T_{h}-T_{c}\right)$ for $\frac{t_{1}}{\tau_{1}}=\frac{t_{2}}{\tau_{2}}=0.25$.

For $\tau_{1}>>t_{1}$ expansion of the exponents and regarding $\tau_{1}=\tau_{\text {Stal }}$ yields

$$
\Delta T=\left(T_{h}-T_{c}\right) \cdot \frac{t_{1}}{\tau_{\text {Stal }}}=\left(T_{\max }-T_{\min }\right) \cdot \frac{t_{1} \kappa \pi^{2}}{D^{2}}
$$

Therefore one finds from Eq. 28

$$
\begin{array}{ll}
\delta_{\text {year }}=1.4 \cdot 10^{-6}\left(T_{h}-T_{c}\right) \cdot \frac{t_{1} \kappa \pi^{2}}{D} & {[\mathrm{~m} / \text { year }]} \\
=3.3 \cdot 10^{-7} \frac{\left(T_{h}-T_{c}\right)}{D} & {[\mathrm{~m} / \text { year }] \text {, with } \mathrm{t}_{1}=12 \mathrm{~h}}
\end{array}
$$

It should be noted that this number is valid for $\mathrm{D}>1 \mathrm{~m}$ and presents an upper limit, because we have assumed tacitly that the temperature inside the stalagmite is homogenous and equal to the 
surface temperature.

Eqs. 28 and 34 show that for stalagmites with diameters $\mathrm{D}$ between $0.1 \mathrm{~m}$ to several meters and temperature differences during night and day of $10^{\circ} \mathrm{C}$, corrosion rates are on the order of $10^{-4}$ to $10^{-5} \mathrm{~cm} /$ year.

Auler and Smart (2004) have estimated rates of corrosion on stalagmites by measuring the depth of the weathered rind and determining the age of the unaltered speleothem calcite below. The highest values they observed was $4 \cdot 10^{-5} \mathrm{~cm} /$ year. In most cases the rates were lower by one to two orders of magnitude.

\section{FIELD EXPERIMENTS TO MEASURE CONDENSATION CORROSION}

Tarhule-Lips and Ford (1998) suspended gypsum plates of about $1 \mathrm{~cm}$ in thickness on nylon strings for about one year in flank-margin caves of the Caribbean. From the measured weight loss they report corrosion rates of $2.4 \cdot 10^{-2} \mathrm{~cm} /$ year.

The thermal behavior of such isolated plates is very similar to that of stalagmites with diurnal variation of temperature and Eq. 28 remains valid if one replaces the diameter D by the thickness of the plate. From this one obtains $\delta \approx 1.4 \cdot 10^{-5} \mathrm{~cm} /$ year, assuming $\Delta \mathrm{T}=10 \mathrm{~K}$. This is three orders of magnitude lower than the experimental findings. It should be noted that these gypsum plates reach thermal equilibrium after a time of only a few minutes. After this time condensation stops and renewed cooling and subsequent heating are necessary to revive it.

Sarbu and Lascu (1997) report condensation rates of water in Movile-Cave, Romania, where they collected water from a $10 \mathrm{~cm}$ by $10 \mathrm{~cm}$ glass plate suspended at a distance of $10 \mathrm{~cm}$ from the cave wall. Movile cave is heated by a hydrothermal lake with water temperature of $21^{\circ} \mathrm{C}$. In its upper level, where the glass plate was suspended air temperature is $21^{\circ} \mathrm{C}$, but the temperature of the cave walls is between $19.4^{\circ}$ and $15.7^{\circ} \mathrm{C}$. In this case the glass plate achieves thermal equilibrium after a few minutes. The observed high run-off rates of about $20 \mathrm{~g} / \mathrm{month}$ cannot be explained by condensation. From Eq. 27 one obtains only $2.5 \mathrm{~g} / \mathrm{month}$ for a plate of $1 \mathrm{~cm}$ thickness.

Summarizing, we state that condensation to small scale objects $(0.1-1 \mathrm{~cm})$ is subject to diurnal variations of temperature. In thermal stable cave environments, or where variations of temperature change seasonally, it can be excluded.

\section{RÖHRENKARREN, A SMALL SCALE EXAMPLE OF CONDENSATION CORROSION}

Recently Simms (2003) reported on vertical, upward tapering tubes in limestone exposed in the epiphreatic zone at the shores of several lakes in Ireland. The dimensions of these solutional features comprising almost perfect circular tubes are between 1 to $5 \mathrm{~cm}$ in diameter and up to 30 $\mathrm{cm}$ in length.

Simms suggests that these "Röhrenkarren" originate from condensation corrosion within air pockets trapped by seasonal high stands of the lake. During March 2000 water temperature $T_{w}$ stayed nearly constant, whereas the temperature of the overlying rock showed diurnal variations, fluctuating around the water temperature with amplitude of about $5^{\circ} \mathrm{C}$. In winter time, when surface temperatures become low extended periods of rock temperatures $T_{R}$ below water temperature are 
likely. Therefore conditions for condensation corrosion to operate are valid.

The lake water is saturated with respect to calcite such that dissolution of the rock in contact with water is excluded. Since the region of the lakes was glaciated about $15 \mathrm{ky}$ ago, rates of dissolution were estimated about $2 \cdot 10^{-3} \mathrm{~cm} /$ year, if one assumes continuous dissolution to present. With this information it is possible to test our theoretical predictions. The distance between the surface of the rock to the apex of the Röhrenkarren is on the order of meters. Therefore thermal equilibrium is attained in a few days. During winter time an extended period of rock temperatures $T_{R}$ several degrees below that of the lake water supports condensation in a steady state. To estimate the rates we use Eq. 19. In the initial state of the evolution of the Röhrenkarren air is entrapped on irregularities of the rock. The geometry of this bubble could be approximated by a half-sphere with radius $\mathrm{R}$ as depicted in Fig. 9. The air entrapped is stagnant, due to the closed conditions. Therefore, diffusion of vapor from the water surface to the rock wall is through this stagnant air. $\varepsilon$ in Eq. 19 must therefore be replaced by the length $L$ of the tube.

The retreat of bedrock is focused to the apex, because heat flow is highest there, whereas the walls exhibit lower heat flow. This way, a circular tube can propagate upwards into the bedrock.

Using Eq. 19 one finds

$$
\frac{d L}{d t}=1.35 \cdot 10^{-8} \frac{\left(T_{W}-T_{R}\right)}{L+5.4 \cdot 10^{-2} R} \quad[\mathrm{~m} / \text { year }]
$$

Initially $\mathrm{L}=\mathrm{R}$, therefore to a good approximation

$$
\frac{d L}{d t}=1.35 \cdot 10^{-8} \frac{\left(T_{W}-T_{R}\right)}{L} \quad[\mathrm{~m} / \text { year }]
$$

Initially with $\mathrm{L}=0.01 \mathrm{~m}$ the growth rate is $1.3 \cdot 10^{-4} \mathrm{~cm} /$ year K. Since condensation is active only during cold weather this must be reduced by a factor of 0.3 or so, to about $5 \cdot 10^{-5} \mathrm{~cm} /($ year K). When the length increases the growth rate drops with $1 / \mathrm{L}$.

During the growth of the tube the entrapped air is in contact with the lake water and consequently $\mathrm{p}_{\mathrm{CO} 2}$ in this air is in equilibrium with the $\mathrm{p}_{\mathrm{CO} 2}$ in the water, which can enhance dissolution rates by a factor of two for $\mathrm{p}_{\mathrm{CO} 2}=2 \cdot 10^{-3} \mathrm{~atm}$, likely in lake water. Therefore with a temperature difference of 10 $\mathrm{K}$ maximal rates are $10^{-3} \mathrm{~cm} /$ year, dropping to $10^{-4} \mathrm{~cm} /$ year when a depth $\mathrm{L}$ of $10 \mathrm{~cm}$ is reached.

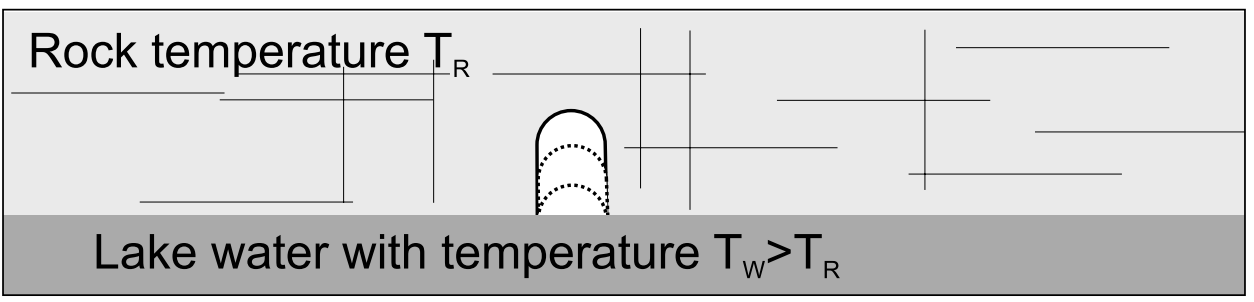

Fig. 9: Röhrenkarren: A slab of rock with a depth of a few meters is exposed to the surface. Its bottom is flooded by the water from the lake. This way air is entrapped. An initial irregularity of radius $R$ (dotted line) grows into a cylindrical shape of length $L$. The temperature of the air inside is close to the water temperature. In winter time the surface temperature is lower than that of the lake water and condensation is active. 


\section{DISCUSSION}

To illustrate our theoretical results we give a numerical solution of a representative example.

Fig. 10 represents a rectangular cave conduit parallel to the surface of a limestone plateau. It is located at a depth $25 \mathrm{~m}$ below ground and its cross section is $10 \mathrm{~m} \mathrm{x} 10 \mathrm{~m}$. Inside this cave the air temperature is $10^{\circ} \mathrm{C}$ and relative humidity is $100 \%$. The temperature at the surface is $0^{\circ} \mathrm{C}$. Note that only the temperature difference is significant. The other boundaries are assumed to be adiabatic, and cannot transmit heat. This is an approximation, which is valid for $t<\mathrm{y}^{2} / \kappa$, where $\mathrm{y}$ is the distance of the cave to the outer limit. $t=y^{2} / \kappa$ is the time when the thermal front reaches the adiabatic boundaries. We solve the differential heat conduction equation

$$
\frac{\partial T}{\partial t}=\kappa \cdot\left(\frac{\partial^{2} T}{\partial y^{2}}+\frac{\partial^{2} T}{\partial z^{2}}\right)
$$

with the boundary conditions, as discussed above by a finite difference program.

Fig. 11 illustrates the results. It shows isotherms as they evolve in time. At the beginning $\left(1 \cdot 10^{6}\right.$ s, Fig. 11a) an almost circular temperature field has developed, symmetrical around the conduit. The temperature has changed only in the vicinity of the cave. After $10^{7} \mathrm{~s}$ (Fig. 11b) the distance the temperature front has propagated is about, $\left(10^{7} \kappa\right)^{1 / 2}=2.4 \mathrm{~m}$, close to what we see in Fig. 11a. After $2 \cdot 10^{8} \mathrm{~s}$ (Fig. 11c). After $1 \cdot 10^{9} \mathrm{~s}$ (Fig. 11e) a thermal gradient develops, directed from ceiling of the cave toward the surface. Most of the heat from the ceiling flows vertically to the surface. This can be seen from the flow lines depicted in Fig. 11. In this region the temperature distribution becomes stable in time, as can be visualized in Figs. 11d, e, f. Keeping in mind that $\tau_{s}=25^{2} / \pi_{\pi}^{2} \kappa_{\kappa} \approx 10^{8} s$ (confer Eq. 15) this is a reasonable result.

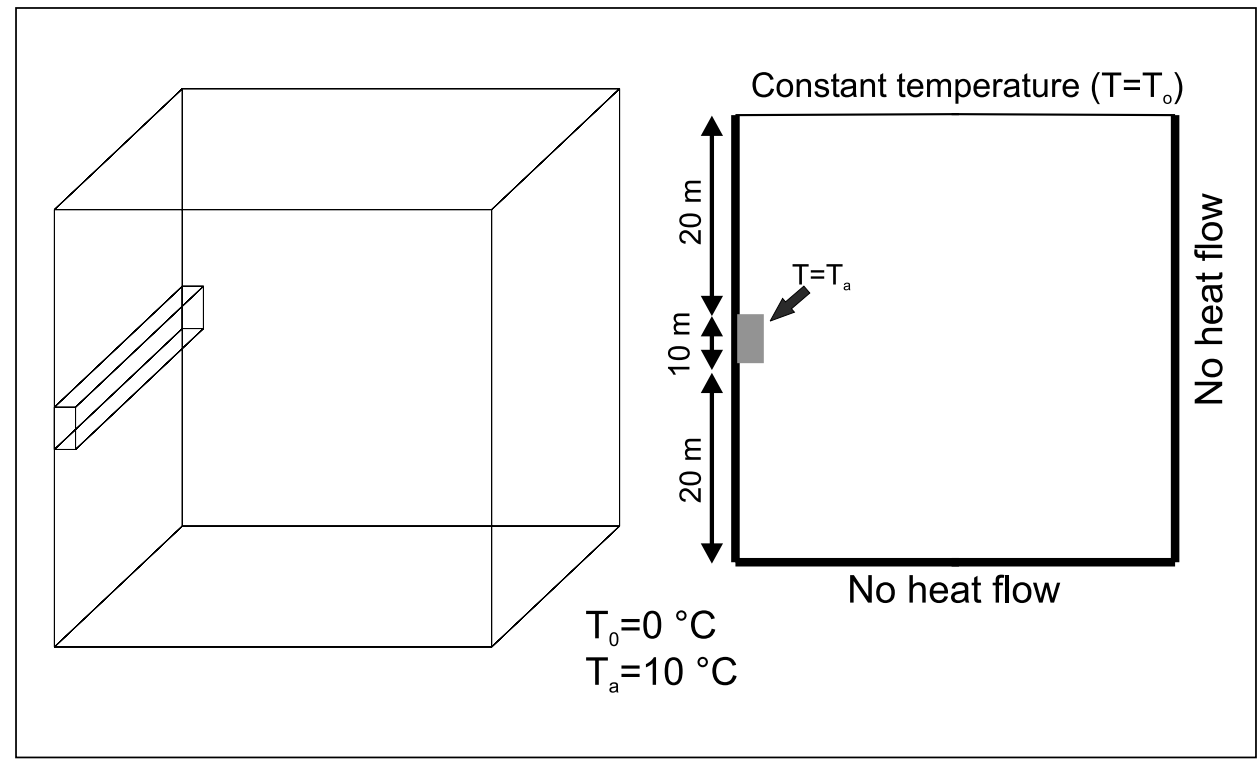

Fig. 10: Modeling domain of a rectangular conduit. Only the right half is shown, because of the mirror symmetry. The surface temperature is $T=T_{0}$. All other boundaries are impermeable for heat flow. 

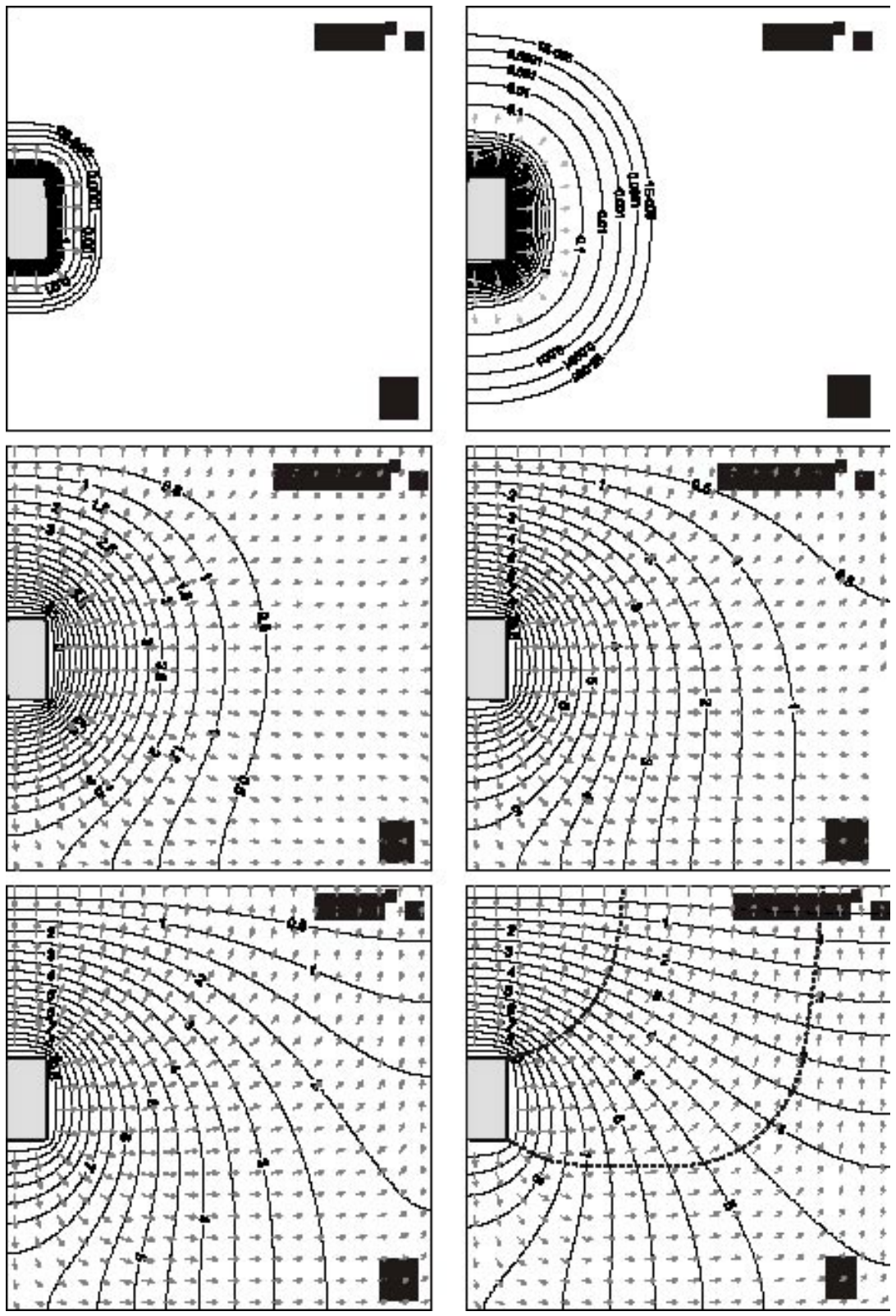

Fig. 11: Evolution of isotherms and heat flow, represented by gray arrows in the domain of Fig. 10 at various times. The dotted lines in Fig. 11d separate the regions of heat flow from the ceiling, the side walls, and the bottom surface of the cave. 

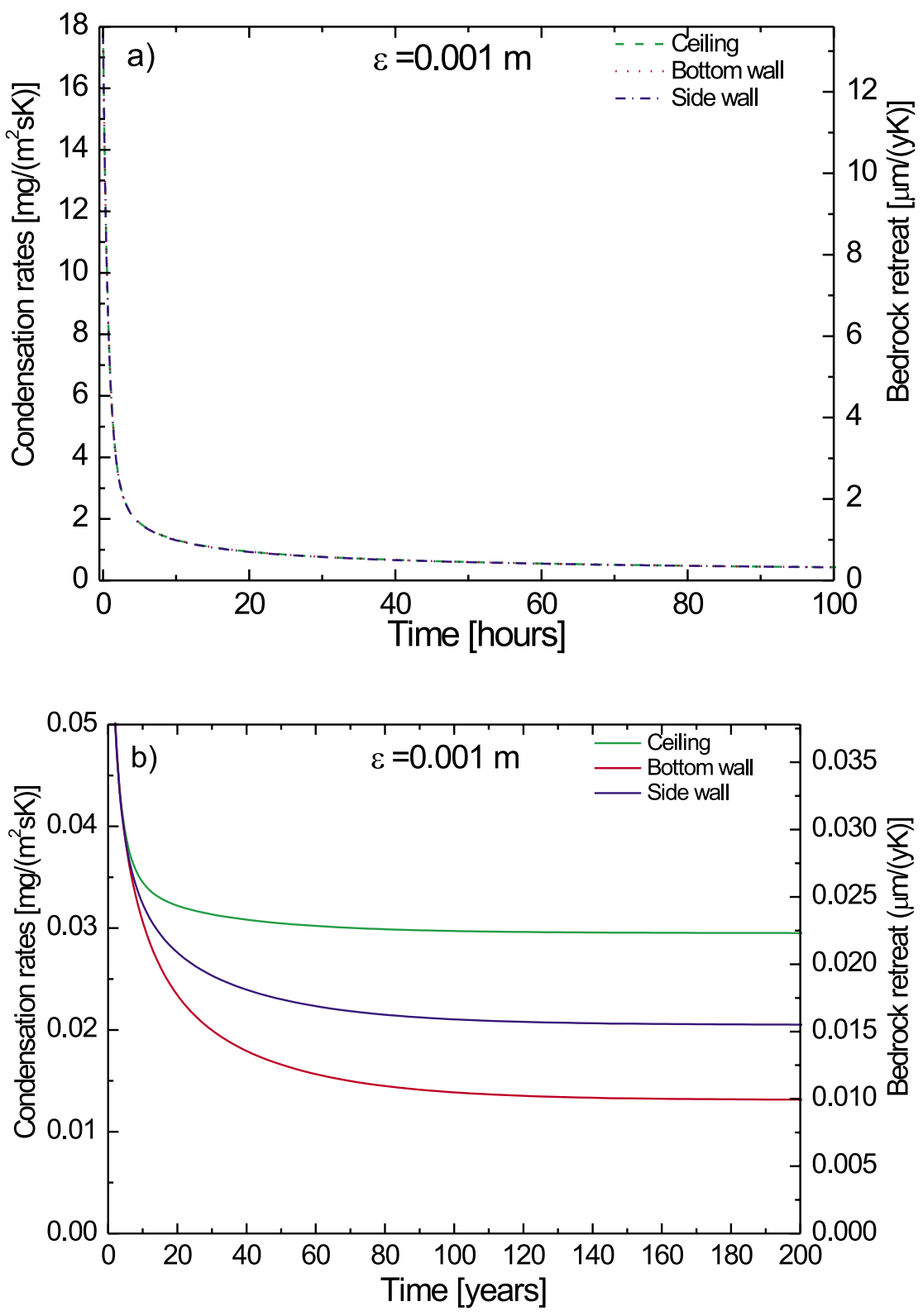

Fig. 12: Time dependence of condensation rates and retreat of bedrock for the ceiling, the side wall and bottom wall of the conduit for times smaller than 100 hours $(a)$ and for long times (b). Note that initial rates (up to 10 y) are equal. 
The dotted lines in Fig. 11f border the regions of heat flow from the ceiling, the side wall and the floor towards the surface. The average distance of the heat flow from the side wall to the surface is larger by about a factor of 2 compared to that of the ceiling. Therefore the time until the temperature field becomes stationary there, is longer by a factor of 4 . Finally the heat flow from the floor exhibits still longer effective flow paths towards the surface. Consequently the time until a stationary temperature distribution is established there, becomes also longer by a factor of about 4 , compared to its neighboring region.

This behavior is shown in Fig. 12. Its left hand ordinate shows the rates of condensing water in $\mathrm{g} / \mathrm{m}^{2} \mathrm{~s}$ as a function of time and the right hand ordinate the retreat of the cave walls for a temperature difference of $1 \mathrm{~K}$. For times $t \leq 1 \cdot 10^{9} s$ all curves are identical because as shown by Figs. 11a-d the boundaries do not yet influence the temperature distribution. Initially, as predicted, a sharp decline is seen which is followed by an intermediate and a slow region of decreasing rates. Compare to Figs. 3 and 4.

First, after 20 years the curve for the ceiling becomes constant, whereas the curve for the side wall shows still a slow decline and becomes constant after 40 years. A similar behavior is also seen for the rates from the floor. From the rate of condensation to the ceiling one finds a retreat of bedrock by $2.3 \cdot 10^{-8} \mathrm{~m} /($ year $\cdot \mathrm{K})$. From the approximation expressed by Eq. 22 one finds $2.4 \cdot 10^{-8} \mathrm{~m} /(\mathrm{year} \cdot \mathrm{K})$. In view of the approximations used, this proves our general concept.

Summarizing, the general properties of heat flow and condensation rates estimated from the idealized one-dimensional model is confirmed by numerical calculations on 2D-models, approximating reality more accurately. This shows that the simple analytical expressions of Eqs.7, 10, 14 and 18 are sufficiently accurate to estimate rates of condensations in relevant geological situations.

We now turn to periodic variations of the temperature of the cave air. To this end we assume $\mathrm{T}_{\mathrm{a}}=15^{\circ} \mathrm{C}$ during the first 12 hours of the day and $\mathrm{T}_{\mathrm{a}}=5^{\circ} \mathrm{C}$ during the $12 \mathrm{~h}$ of the "night". Fig. 13a shows the results if one assumes that the water, which accumulates during the day, evaporates during the night. If no evaporation takes place during the night, cooling becomes slower than heating during the day. Fig.13b shows the variations of wall temperature in this case. It takes about 20 days until the temperature amplitudes become constant.

Fig. 14 shows the total amount of water which has condensed to one square meter of the cave wall as a function of time for both cases. The stationary rates depend only on the difference between day and night temperatures, and are independent on the surface temperature at $\mathrm{z}=0$. Independently on that temperature, in the heating period the temperature of the rock approaches $T_{h}$ closely. Then during cooling is cannot drop below $\mathrm{T}$. Finally a stationary state is reached when this minimum temperature at the cave wall determines the initial conditions at each heating period, and $\Delta T=T_{\max }-T_{\min }$ is independent on the surface temperature at $\mathrm{z}=0$.

One has to consider that such diurnal variations are operative only during the summer season, about one third of a year. Therefore the retreat of bedrock must be reduced correspondingly.

This result is independent on the depth Z, as can be visualized from Fig. 3. During first 24 hours and up to 180 days the rise of temperature and condensation rates are independent of depth $\mathrm{Z}$. When stationary state is reached one obtains a retreat of bedrock by $10.4 \mu \mathrm{m} /$ year for the case with nocturnal evaporation and $\Delta T=10^{\circ} \mathrm{C}$, and $2.7 \mu \mathrm{m} /$ year if evaporation is absent. See Fig. 14. This is higher by one order of magnitude than retreat of bed rock of $0.2 \mu \mathrm{m} /$ year for stationary temperature with $\Delta T=10^{\circ} \mathrm{C}$ (see Fig. 5) $2.7 \mu \mathrm{m} /$ year. This is an important result, which shows 

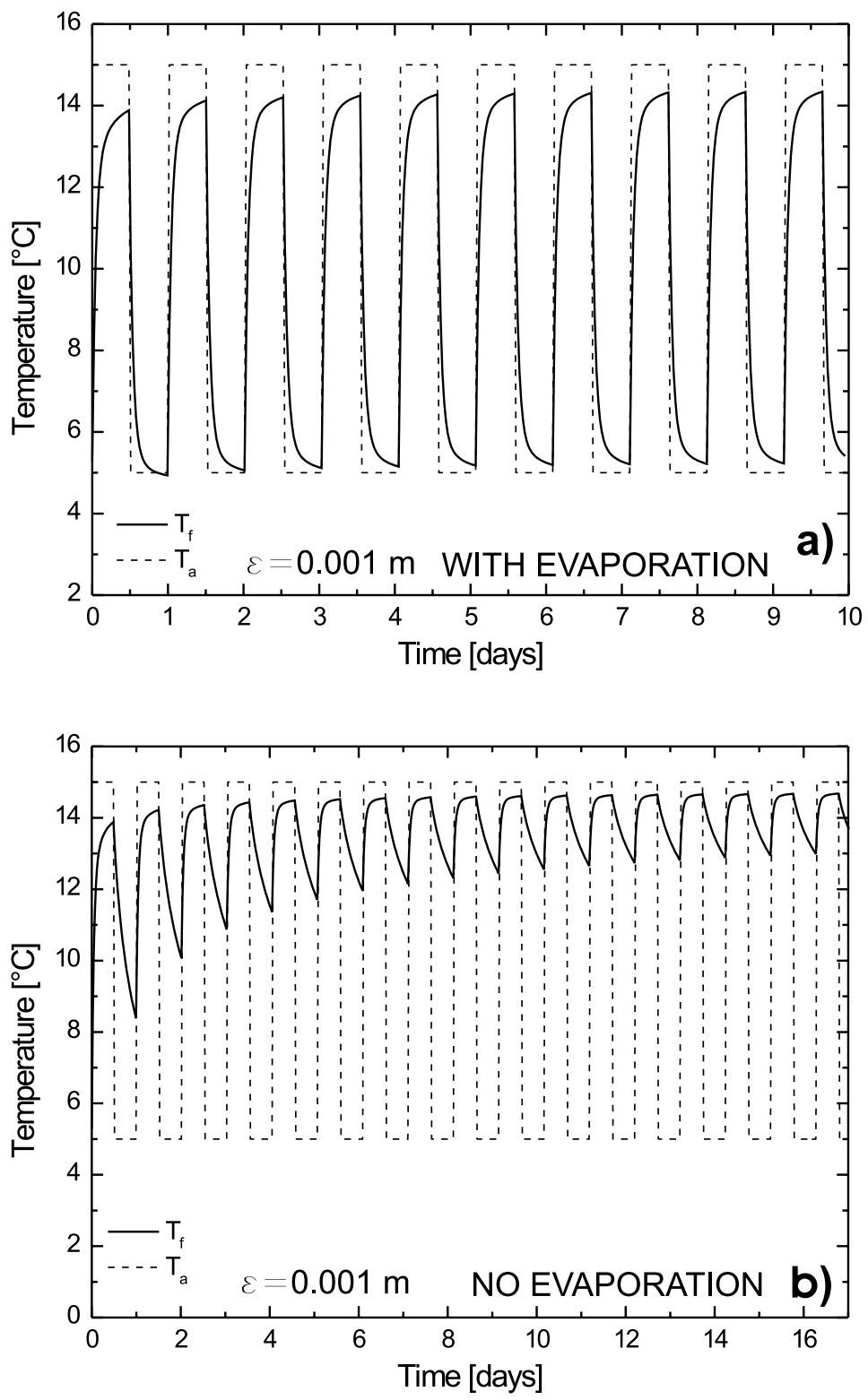

Fig. 13: a) Variation of temperature for diurnal temperature changes in the domain of Fig.10. The dotted line shows the temperature $T_{a}$ of the air in the cave, varying between $5^{\circ} \mathrm{C}$ and $15^{\circ} \mathrm{C}$. Surface temperature is $0^{\circ} \mathrm{C}$. Condensation during day, evaporation during night. b) Accumulated total amount of condensed water and total retreat of bedrock as a function of time. 
that significant retreat of rock by condensation corrosion is possible at locations, where wet warm air with a dew point temperature above that of the cave wall enters during the day. But during the night cool air with dew point above the actual wall temperature must enter. Such locations are favorable only close to the entrance.

Finally we consider seasonal variations with the same thermal boundary conditions as in the previous case but with changes of temperature every six months. The results are shown in Fig. 15 .

Steady state amplitudes of temperature are obtained after about 10 years. They are about $50 \%$ of the initial amplitudes. The corresponding amount of condensed water is given in Fig. 15b For the linear region a retreat of bedrock $0.33 \cdot 10^{-6} \mathrm{~m} /($ year $\mathrm{K})$ is obtained. This is about one tenth of the maximal value calculated by the initial condensation by using Eq. 25 . These results are independent on the depth $\mathrm{Z}$ for the same reasons as discussed above.

A final comment must be given. In all our considerations we have assumed that the relative humidity of the cave air is $100 \%$. Therefore our results give maximal values of bedrock retreat. Furthermore all values given relate to limestone. These values can be approximately converted to gypsum by multiplication by a factor 50 , which takes into consideration the higher solubility and lower density of gypsum.

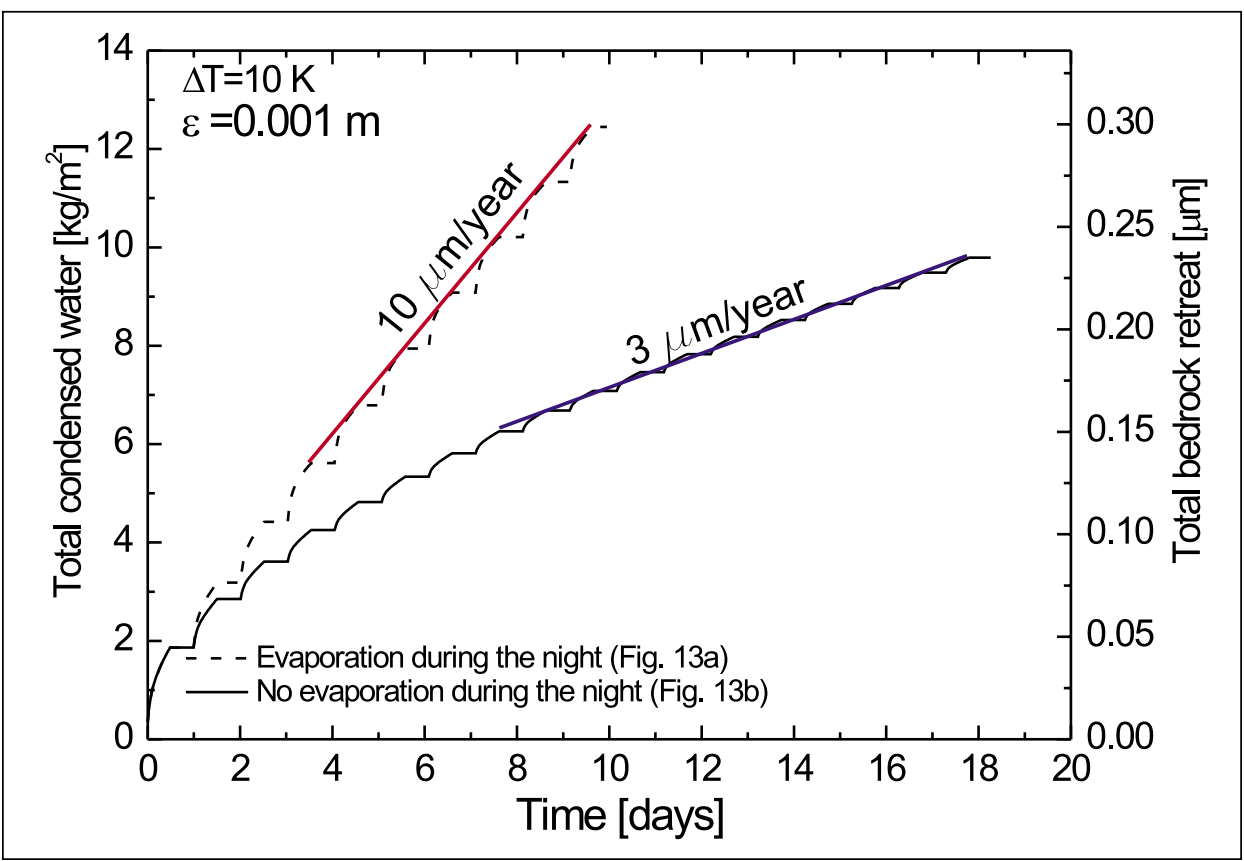

Fig. 14: Boundary conditions as in previous Fig. 13. Accumulated total amount of condensed water and total retreat of bedrock as a function of time. 

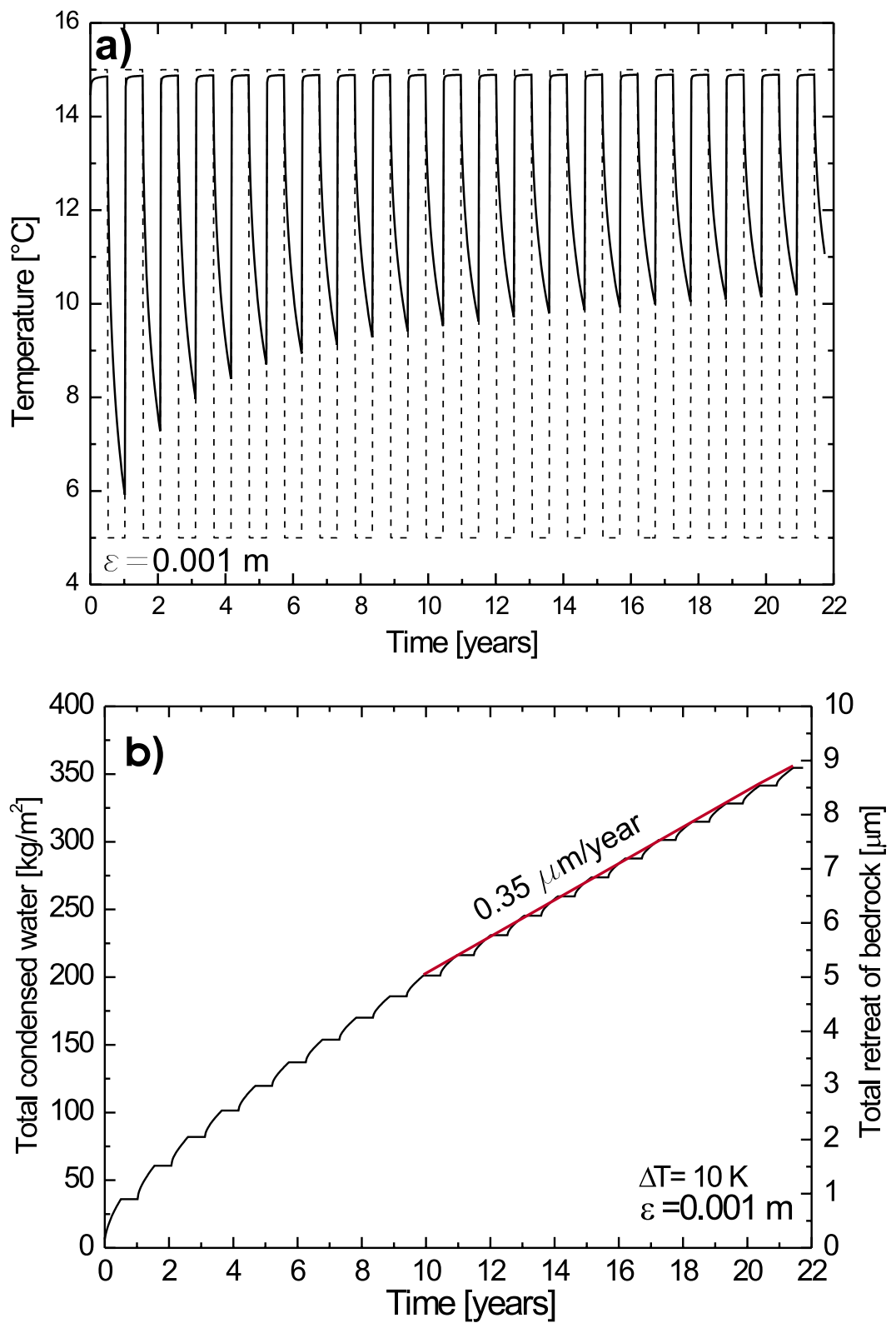

Fig. 15: a) Variation of temperatures for seasonal changes in temperature between $5^{\circ} \mathrm{C}$ and $15^{\circ} \mathrm{C}$. Condensation during the warm season, no evaporation during the cold season. b) Accumulated total amount of condensed water and total retreat of bedrock as a function of time. 


\section{CONCLUSION}

Condensation of vapor from warm humid air to the colder walls of a cave is controlled by transport of heat from the warmer air and the heat of condensation into the surrounding rock. At the onset of condensation to the initially cold cave wall, the wall temperature rapidly increases and then slowly approaches a stationary state. Therefore initial condensation rates are high, but at stationary state they are lower by several orders of magnitude.

We have shown that a one dimensional heat transfer model is suitable to estimate the condensation rates within the order of magnitude. From these rates the retreat of bedrock can be calculated.

For constant air temperature $\mathrm{T}_{\mathrm{a}}$ in the cave, rates are proportional to the temperature difference $\mathrm{T}_{\mathrm{a}}-\mathrm{T}_{\mathrm{o}}$, where $\mathrm{T}_{\mathrm{o}}$ is the average annual temperature at the surface of rock massive hosting the cave. Retreat of bedrock in this case is in the order of tenths of a micrometer per year is $\mathrm{T}_{\mathrm{a}}-\mathrm{T}_{\mathrm{o}}=10^{\circ} \mathrm{C}$.

When the cave temperature varies diurnally or seasonally, the driving force for condensation is the amplitude of temperature variations. For diurnal variations, retreat of bedrock is about $3 \mu \mathrm{m} /$ year for amplitude of $10^{\circ} \mathrm{C}$, whereas seasonal variations with the same amplitudes cause a retreat of bedrock by $0.3 \mu \mathrm{m} / \mathrm{year}$.

\section{APPENDIX}

In our theoretical considerations we have assumed that in any case the water flowing down from the cave walls has become saturated with respect to limestone or gypsum, respectively. This crucial assumption needs experimental proof. We therefore have set up an experiment, with condensation rates similar to those in nature.

Fig. A1 shows the experiment schematically. A closed vessel contains water at the bottom, which can be heated by a heating wire, controlled by a contact thermometer (4). It is stirred by a magnetic stirrer (5). A conductometer (6) is used to measure the conductivity. At the top we have a limestone or gypsum cupola (2) which is cooled by water with temperature of $20 \pm 0.2^{\circ} \mathrm{C}$ entering at inlet (3). Inlet (7) provides the possibility for exchanging the interior atmosphere. Thus it is possible to establish a partial pressure of $\mathrm{CO}_{2}$ up to $1 \mathrm{~atm}$. At the upper part of the vessel there is a ring, which collects the condensed water flowing down from the cupola and guides it to the collection bottle (8). The temperature difference between the water and the cooler rock cupola can be maintained between $3^{\circ} \mathrm{C}$ up to $8^{\circ} \mathrm{C}$. The experiments were performed with a temperature difference of $5^{\circ} \mathrm{C}$.

It should be noted that this set up does not simulate the situation in nature, since the water film will attain a steady temperature in a very short time due to cooling of the cupola. Nevertheless it will answer the question about saturation of the condensed water flowing down from the rock. Two kinds of experiments have been performed.

In the first experiment we collected the water flowing down from the rock and analyzed it by standard titration methods for $\mathrm{Ca}$. We first performed the experiment with a cupola made of plaster of Paris. In this case the amount of condensed water flowing into bottles was about $15 \mathrm{~g} /$ day, equivalent to $1.7 \mathrm{~kg} /\left(\mathrm{m}^{2} \mathrm{day}\right)$. The result of the analysis for Ca showed saturation with respect to gypsum.

Similar experiments were performed using a limestone cupola. Here because of a different geometry the amount of condensing water was reduced to $3 \mathrm{~g} /$ day equivalent to $0.69 \mathrm{~kg} /\left(\mathrm{m}^{2}\right.$ day). The experiments were performed with an atmosphere of different $\mathrm{CO}_{2}$-partial pressures $\left(1 \cdot 10^{-3}, 5 \cdot 10^{-3}\right.$, $\left.1 \cdot 10^{-2}, 2 \cdot 10^{-1}, 1 \mathrm{~atm}\right)$. In all cases the collected water was saturated with respect to calcite. 
In a second kind of experiment the ring was removed and the condensed water flows down to the reservoir, thus increasing its conductivity. In all experiments we observed a linear increase of conductivity with time for several days. For limestone at $\mathrm{p}_{\mathrm{CO} 2}=1 \cdot 10^{-3} \mathrm{~atm}$ the rise was $2 \mu \mathrm{S} / \mathrm{day}$ which increased up to $20 \mu \mathrm{S} /$ day for $\mathrm{p}_{\mathrm{CO} 2}=1 \mathrm{~atm}$. If the down flowing water is saturated, then in these experiments the increase $\Delta \sigma$ in conductivity must be proportional to the saturation concentration $\mathrm{C}_{\mathrm{s}}$. From the equilibrium chemistry of the system $\mathrm{H}_{2} \mathrm{O}-\mathrm{CO}_{2}-\mathrm{CaCO}_{3}$ it is known that $\mathrm{C}_{\mathrm{s}}$ is given by

$$
\begin{aligned}
& C_{S}=C_{1} \cdot\left(P_{\mathrm{CO} 2}\right)^{1 / 3} \\
& \Delta \sigma=C_{2} \cdot\left(P_{\mathrm{CO} 2}\right)^{1 / 3}
\end{aligned}
$$

$\mathrm{C}_{1}$ and $\mathrm{C}_{2}$ are constants.

We have plotted the experimental data logarithmically versus $\mathrm{p}_{\mathrm{CO} 2}$ as depicted in Fig. A2. Clearly we obtain a straight line with slope of $0.33 \pm 0.02$. This proves the underlying assumption of saturation with respect to calcite.

We have furthermore estimated the thickness of the film by removing the condensed water from the rock surface with a tissue and weighting its weight increase. We found a thickness $\delta=5 \cdot 10^{-3} \mathrm{~cm}$.

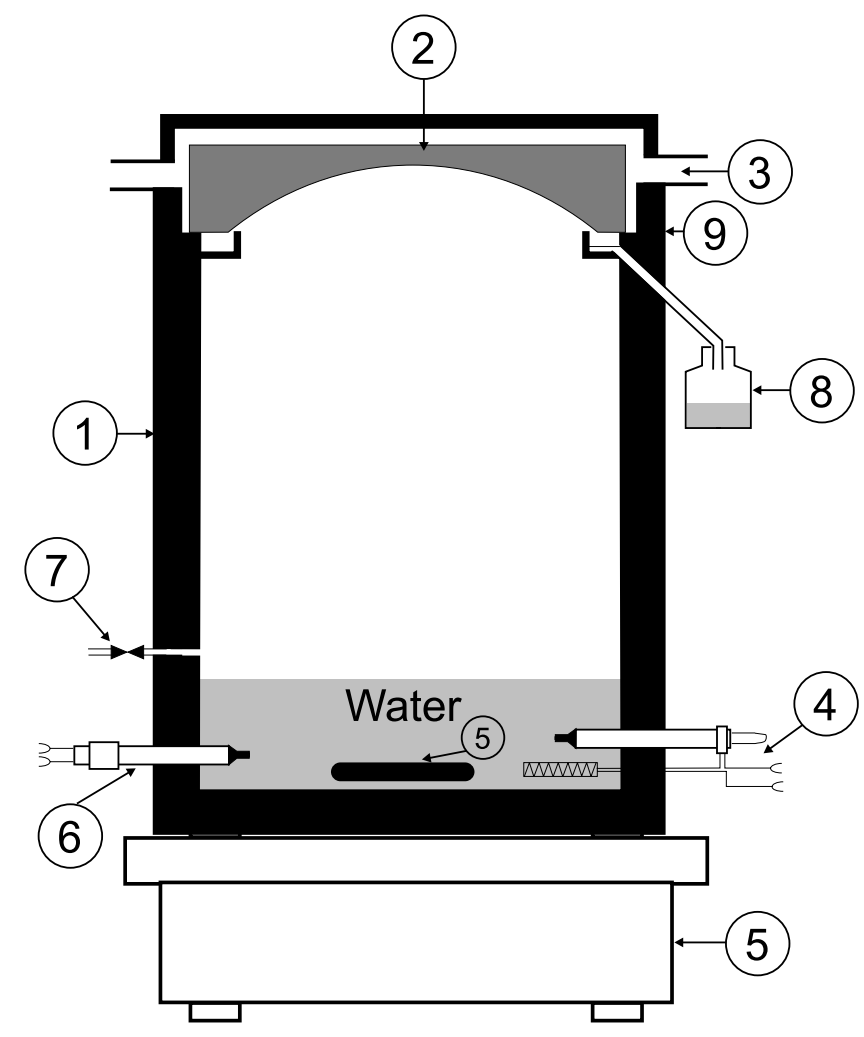

Fig. Al: Experimental set up. See text. 
Using this value it is possible to confirm the experimental results by the following arguments. The dissolution kinetics of calcite covered by thin films of water is given by the rate equation (Buhmann \& Dreybrodt 1985)

$$
R=\alpha\left(C_{S}-C\right) \quad\left[\frac{\mathrm{mmol}}{\mathrm{cm}^{2} s}\right]
$$

$\mathrm{C}$ is the actual calcite concentration in the film covering the calcite surface. Values of $\alpha$ are tabulated and range from $0.3 \cdot 10^{-5}$ up to $3 \cdot 10^{-5} \mathrm{~cm} / \mathrm{s}$ for natural environments increasing with increasing $\mathrm{p}_{\mathrm{CO} 2}$. The time necessary until such a film achieves $95 \%$ saturation is given by

$$
T=3 \cdot \frac{\delta}{\alpha}
$$

This gives a maximum value of about 1 hour. From the total amount of water constituting the film $\left(0.22 \mathrm{~cm}^{3}\right)$, and the amount condensing per day $\left(3 \mathrm{~cm}^{3}\right)$ the average time water spends at the surface before flowing back is about 1.5 hours, sufficient to come close to saturation.

In the case of gypsum dissolution proceeds by molecular diffusion. Therefore $\alpha$ is given by $\mathrm{D} / \delta$, where $\mathrm{D} \approx 1 \cdot 10^{-5} \mathrm{~cm}^{2} \mathrm{~s}^{-1}$ is the diffusivity of the Ca-ion. Thus $\alpha \approx 3 \cdot 10^{-3} \mathrm{~cm} / \mathrm{s}$ and $\mathrm{T} \sim 2 \mathrm{~s}$.

Thus the achievement of saturation can be taken for granted in both gypsum and limestone caves.

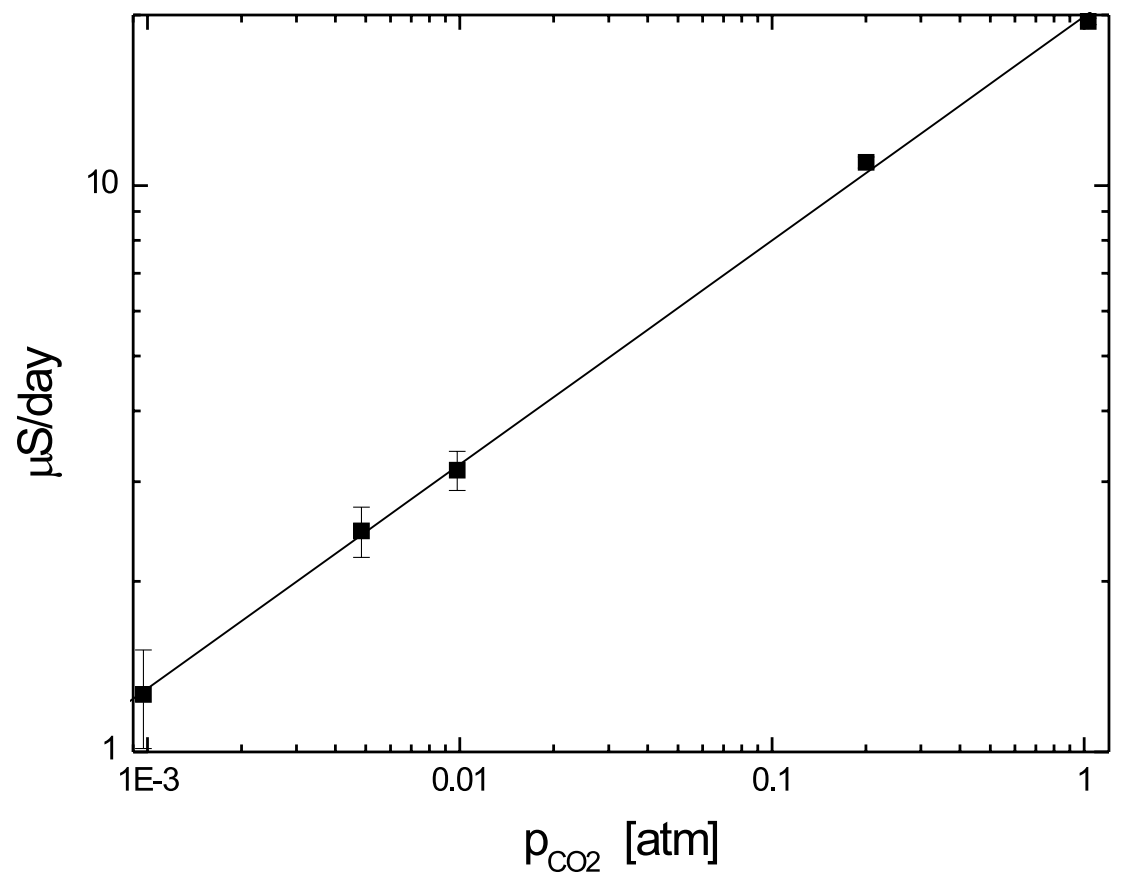

Fig. A2: Increase of conductivity for condensation corrosion on the limestone cupola as a function of $\mathrm{CO}_{2}$-pressure. 


\section{REFERENCES}

Audra, P., Bigot, J.Y. \& Mocochain, L., 2002: Hypogenic caves in Provence (France): Specific features and sediments.- Acta Carsologica, 31/3, 33-50.

Auler, A.S. \& Smart, P.L., 2004: Rates of condensation corrosion in speleothems.- Speleogenesis and evolution of karst aquifers, www.speleogenesis.info, 2/2.

Avramidis, P., Hong, J., Barnes, C. \& James, J.J.,2001: A new method of measuring condensation corrosion.- 13th International Congress of Speleology, Brasilia, DF.

Badino, G., 1995: Fisica del Clima Sotterraneo.- Instituto Italiano di Speleologia, Bologna, 136 pp.

Beek, W.J. \& Muttzall, K.M.K., 1975: Transport phenomena.- Wiley, London; New York, x, 298 $\mathrm{pp}$

Buhmann, D. \& Dreybrodt, W., 1985: The kinetics of calcite dissolution and precipitation in geologically relevant situations of karst areas.1. Open system.- Chemical geology, 48(1-4), 189-211.

Calafora, J.M., Dell'Aglio, A. \& Forti, P.,1993: Preliminary data on the chemical corrosion in gypsum karst: 1- The Sorbas region (Spain).- XI International Congress of Speleology, Beijing, China, 77-99.

Carslaw, H.S. \& Jaeger, J.C., 1959: Conduction of heat in solids.- Oxford University Press, Oxford, 510 pp.

Cigna, A. \& Forti, P., 1986: The speleogenetic role of air flow caused by convection.- International Journal of Speleology, 15, 41-52.

Dublyansky, V.N. \& Dublyansky, Y.V., 2000: The role of condensation in karst hydrogeology and speleogenesis.- In: A. Klimchouk, D.C. Ford, A. Palmer \&W. Dreybrodt (Editors), Speleogenesis: Evolution of karst aquifers.- National Speleological Society, 100-111.

Incropera, F.P. \& DeWitt, D.P., 2002: Fundamentals of heat and mass transfer.- J. Wiley, New York, $981 \mathrm{pp}$.

Klimchouk, A., Cucchi, F., Calafora, J.M., Aksem, S., Finocchiaro, F. \& Forti, P., 1996: Dissolution of gypsum from field observations.- International Journal of Speleology, 25(3-4), 37-48.

Luikov, A.V., 1968: Analytical Heat Diffusion Theory.- Academic Press.

Sarbu, S.M. \& Lascu, C., 1997: Condensation corrosion in Movila cave, Romania.- Journal of Cave and Karst Studies, 59(3), 99-102.

Simms, M.J., 2003: The origin of enigmatic, tubular, lake-shore karren: A mechanism for rapid dissolution of limestone in carbonate-saturated waters.- Physical Geography, 23, 1-20.

Tarhule-Lips, R.F.A. \& Ford, D.C., 1998: Condensation corrosion in caves on Cayman Brac and Isla de Mona.- Journal of Cave and Karst Studies, 60, 84-95.

Wigley, T.M.L. \& Brown, M.C., 1976: The physics of caves.- In: J.D. Ford \&C.H.D. Cullingford (Editors), The Science of Speleology.- Academic Press, London, 329-58. 
